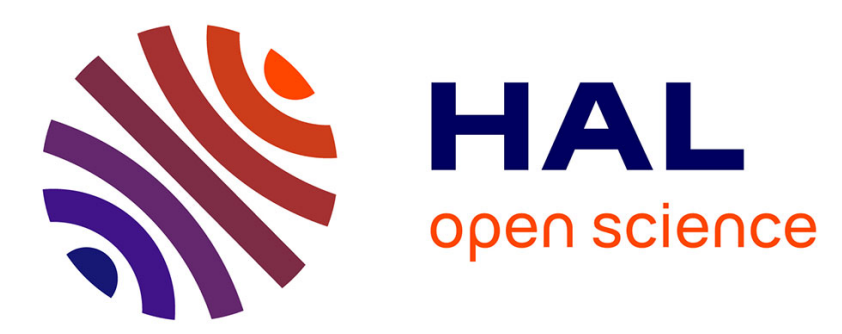

\title{
Bitumen residue on a Late Ceramic Age three-pointer from Marie-Galante, Guadeloupe: Chemical characterization and ligature evidence
}

\author{
Nathalie Serrand, Sibilla Orsini, Erika Ribechini, Fabrice Casagrande
}

\section{- To cite this version:}

Nathalie Serrand, Sibilla Orsini, Erika Ribechini, Fabrice Casagrande. Bitumen residue on a Late Ceramic Age three-pointer from Marie-Galante, Guadeloupe: Chemical characterization and ligature evidence. Journal of Archaeological Science: Reports, 2018, 10.1016/j.jasrep.2018.07.014 . hal02526943

\section{HAL Id: hal-02526943 \\ https://hal.science/hal-02526943}

Submitted on 5 Apr 2020

HAL is a multi-disciplinary open access archive for the deposit and dissemination of scientific research documents, whether they are published or not. The documents may come from teaching and research institutions in France or abroad, or from public or private research centers.
L'archive ouverte pluridisciplinaire $\mathbf{H A L}$, est destinée au dépôt et à la diffusion de documents scientifiques de niveau recherche, publiés ou non, émanant des établissements d'enseignement et de recherche français ou étrangers, des laboratoires publics ou privés. 


\title{
Bitumen residue on a Late Ceramic Age three-pointer from Marie-Galante, Guadeloupe: Chemical characterization and ligature evidence
}

\author{
Nathalie Serrand $^{\mathrm{a}, \mathrm{b}, *}$, Sibilla Orsini ${ }^{\mathrm{c}}$, Erika Ribechini ${ }^{\mathrm{c}}$, Fabrice Casagrande $^{\mathrm{a}}$ \\ a Inrap Grand Sud-Ouest-Départements d'Outre-Mer, Centre archéologique de Gourbeyre, Guadeloupe \\ ${ }^{\mathrm{b}}$ Unité Mixte de Recherche 7209 Archéozoologie et Archéobotanique, Centre National de la Recherche Scientifique-Muséum national d'histoire naturelle, Paris, France \\ ${ }^{\mathrm{c}}$ Université de Pise, Département de Chimie et de Chimie Industrielle, Pise, Italy
}

\section{A R T I C L E I N F O}

\section{Keywords:}

Pre-Columbian Lesser Antilles

Ceramic Age

Three-pointer

Zemi

Guadeloupe

Bitumen

Symbolic representation

\begin{abstract}
A B S T R A C T
Among the most recognizable and enigmatic artefacts found in pre-Columbian archaeological contexts of the Ceramic Age in the Greater and Lesser Antilles is the three-pointer, a triangular shaped object made of various mineral and organic materials. Despite a few ethno-historic mentions and abundant academic speculations, little is known about the social and spiritual dimensions these once animate objects had in the Amerindian Antillean communities. Furthermore, very little can be empirically verified. The wide array of known specimens shows many variations, including the presence/absence of usually poorly preserved traces of black residue, often described as plant tars, resins or gums, or as inorganic bitumen. Well preserved residues of this type have been observed on a three-pointer specimen recently discovered in a Late Ceramic Age context (Troumassoid series, 10th-11th century AD) of the Tourlourous site on the island of Marie-Galante (Guadeloupe, French Lesser Antilles). They have been physico-chemically characterized as bitumen, and they preserve evidence of a specific tying system. These data raise considerations on two points: the necessity to better document these sometimes tenuous clues of tying and adhesion systems implying bitumen (and other glues), and the need to consider that three-pointers (and other artefacts), while actively used in the mediation between social and spiritual dimensions, also have a practical side which should be addressed in technological terms in order to better understand all their dimensions.
\end{abstract}

\section{The world of three-pointers: Between symbolism and function}

Three-pointers ${ }^{1}$ are among the most recognizable and enigmatic artefacts found in Amerindian pre-Columbian archaeological sites in the Antilles. They are characteristic of the Ceramic Age of the Lesser and Greater Antilles, which begins around 500 BCE after a multi-millennia sequence of pre-Ceramic/Archaic occupation by groups who settled most of the Caribbean islands (Boomert, 2000; Keegan, 1994). In the Lesser Antilles, the Ceramic phase is marked by the arrival of horticultural, pottery-making Saladoid peoples coming from the South American mainland (Oliver, 1999; Rouse, 1986, 1992; Rouse and Cruxent, 1963). Typical ceramics of the Cedrosan Saladoid subseries are subsequently found in Trinidad, Tobago, most of the Lesser Antilles and the eastern Greater Antilles as far as the eastern tip of Hispaniola (Bonnissent, 2010; Keegan, 1994, 2000; Rouse, 1986, 1992; Siegel, 2010; Veloz Maggiolo, 1991). During this early phase of the Ceramic
Age, a relative cultural unity is manifested through similarities in the prevailing ceramic assemblages, settlement patterns and economies (Petersen, 1997; Rouse, 1992; Wing and Wing, 1995). A Late Ceramic Age phase is defined after ca. $600 \mathrm{CE} / 800$, when regional ceramic styles diversify within the Ostionoid and Troumassoid series and associated subseries. During this phase the colonization of the entire Lesser and Greater Antilles and the Bahamas is completed. This period of divergent local developments, population movements and increasing social complexity produces a mosaic of societies, not yet fully understood, which dislocates during the contact period after 1492 (Keegan, 2000).

Three-pointers are thought to be indigenous to the pre-Columbian Antilles (Boomert, 2000: 488-489). They are omnipresent throughout the Ceramic Age sequence. They appear as early as the 3rd century BC in Puerto Rico (Rouse and Alegría, 1990: 30-31; Walker, 1993: 44) and during the first few centuries $\mathrm{AD}$ in the northeastern Antilles (Hoogland, 1996: 80, 84), especially between eastern Hispaniola and

\footnotetext{
* Corresponding author at: Inrap GSO-DOM, Centre archéologique de Gourbeyre, 97113 Gourbeyre, Guadeloupe.

E-mail addresses: nathalie.serrand@inrap.fr (N. Serrand), sibilla.orsini@gmail.com (S. Orsini), erika@dcci.unipi.it (E. Ribechini), fabrice.casagrande@inrap.fr (F. Casagrande).

${ }^{1}$ Also called trigonoliths in French or cemíes in Spanish.
} 
the Guadeloupean archipelago. They persist through late pre-contact times in the Greater as well as the Lesser Antilles. Most large and sculpted three-pointers occur between eastern Hispaniola and Puerto Rico during the late Taino period.

Their characteristic shape is triangular with three extremities projecting outward. Breukel (2013: 18) defines them as sharing "a basic conical template which often assumes a triangular or oblong threepointed shape," but this shape shows many, sometimes subtle, variations including size. Indeed, specimens vary from tiny objects to very large ones. Some show a concave base, a grooved concavity on the basal surface or a grooved furrow underlining the base. Some are plain while others are decorated with incised facial, corporal or abstract motifs including recurrent herringbone patterns.

In archaeological contexts, three-pointers have been found made of various rocks, corals, shell species and, more rarely, ceramic (Allaire, 1974) or bone (Fewkes, 1922: 155). Some were probably manufactured in wood (Petitjean Roget, 1983) and some possibly in cotton and other soft materials that did not survive in the archaeological record. They are found complete or broken in a variety of deposits including postholes, refuse middens, etc.

Ethno-historical records mention three-pointer-like objects as being imbued with zemis (cemis), that is, spiritual, immaterial, numinous and vital forces that can be related to deities, ancestral spirits or landmarks. This suggests they were not inanimate objects but potentially living social entities invested in socio-economic realms such as fertility, curing power or power legitimization, among others (Boomert, 2000, 2001, 2013; Oliver, 2009; Petitjean Roget, 1997; Rodríguez Ramos et al., 2013; Roe, 1982, 1997; Siegel, 2010).

These objects have drawn much academic attention, debate, and speculation, with attempts at typologies started early in the 20th century (Breukel, 2013; Clerc, 1973, 1976; De Hostos, 1923; Fewkes, 2009 [1907]; Petitjean Roget, 1983; Petit-Jean-Roget, 1993; Veloz Maggiolo, 1970; Walker, 1997), often based upon local, restricted assemblages. Despite the constant research on these objects and various postulates in terms of their function and significance, very little is empirically verifiable (Boomert, 2000: 488-490). This is due to their omnipresence across time, their polymorphic appearance, their subtle as well as largescope variations (in material, size, shaping details, iconography, etc.) and the likely polysemous messages they carry. Their polymorphic nature is probably the reflection of some deep symbolism as well as of variable functions and meanings, evolving in time and across communities and spaces. Deciphering such plastic representations, their meanings and functions-on a local and time t community scale-is a challenging, almost impossible, task with regard to non-writing societies (Testart, 2006). The «sign» being polysemous, a common representation can be associated with a plurality of meanings by dispersion (multiple meanings organised around a major initial content) or even inversion (the same sign having one meaning and its opposite).

Besides the obvious spiritual dimensions three-pointers had in the pre-Columbian Antillean societies, practical or even functional aspects need also be considered for these objects regarding the ways they were handled: they may have been deposited in spiritually animated places (springs, trees, etc.), buried in gardens as symbolically fertilizing energies, and exhibited as power marks by shamans or chiefs. Furthermore, they also may have been involved in utilitarian tasks, as suggested by some scholars (Barbotin, 1987: 15, 65; Petitjean Roget, 1983: 522), such as grinding, pounding or planting. Such various ways of handling, carrying, keeping or showing the three-pointers may have involved additional materials, larger compositions or inclusion in composite objects, implying the potential use of cords or ligatures that sometimes might have been affixed with tarry adhesives. These dimensions may be more accessible to reading by archaeologists and may open ways to start to decipher other dimensions of these objects.

\section{Residues on three-pointers}

The preservation of residues of bitumen or plant extracted tars, resins or gums on three-pointers and other objects is a fairly common phenomenon. The utilization of such products as adhesives, varnishes or coatings for ceramics, canoes or other items among pre-Columbian Antillean populations is sparsely but clearly described or mentioned in descriptions by a few chroniclers (Las Casas, 1957: 36; Oviédo y Valdes, 1959; Pané, 1974) and thus quite commonly inferred for archaeological objects.

Recently physico-chemical analyses have been carried out on rather unique archaeological objects extracted from museum collections, including three-pointers, duhos, wooden sculptures and statuary elements from the Greater Antilles and the Bahamas (Ostapkowicz et al., 2011, 2012, 2013). They confirm that plant extracted resins of the Pinaceae family, especially the Caribbean pine Pinus caribaea, and of the Protium (copal) and Bursera (gum tree) genera were commonly used on this variety of objects. Bitumen is not that often described or retrieved.

When found, such residues usually have appeared on simple archaeological objects, occurring as a few poorly preserved micro-traces fortuitously trapped in surface irregularities. While these residues were probably more common, the probability of their being preserved is a result of the sequence of alterations the discarded three-pointer underwent: i.e., exposure to open air, to humic acids in the archaeological context, intense washing or conservation treatments during archaeological or museum processes.

Although such residues on three-pointers of the Lesser Antilles appear fairly commonly, including a few specimens from Guadeloupe (Clerc, 1974, 1976: 42), they have been described only on a very limited scale (Breukel, 2013). The residues usually appear deteriorated and only partially preserved. While few if any have been physico-chemically analyzed, their nature is often inferred as being plant extracted tars, resins or gums, or bitumen (Breukel, 2013). This is the case for the specimens described with such residues from Guadeloupe (collections of the E. Clerc Museum, Department of Guadeloupe, Le Moule) by E. Clerc (1974, 1976: 42; Durand and Petitjean Roget, 1991). On most of these, the remaining traces are mostly located on both basal points and, in some cases, on the lower surface of the base. This brought Clerc, very early, to suggest that these residues were probable traces of a tying system coated with "bitumen," helping attach the object to a stand or a handle.

In 2012 a three-pointer with exceptionally informative residues was found during an excavation carried out on the Tourlourous site on the southeastern coast of Marie-Galante (southern Guadeloupe, French Lesser Antilles). It was recovered from a Late Ceramic Age context of the site, representing the Troumassoid series. This artefact presents well preserved, remarkable amounts of black residues that generate several working considerations. It is, moreover, associated with other threepointer specimens as well as other artefacts which, although fragmentary, also show residues.

\section{The Tourlourous Troumassoid specimen}

Marie-Galante is an island located in the southern part of the Guadeloupean archipelago, in the French Lesser Antilles (Fig. 1). Its pre-Columbian occupation is fairly well documented, starting with a known pre-Ceramic Age presence during the 2nd millennium BC (Fouéré et al., 2014). Most sites on the island, however, date to the Early Ceramic Age, between the 2nd and 9th centuries AD, and to the Late Ceramic Age, between the 9th and 15th centuries AD (Barbotin, 1970, 1987; Bodu, 1985; Bonnissent, 2011; Boomsma and Isendoorn, 2001; Casagrande, 2013; Chenorkian, 1998; Emond, 1980; Gassies, 1995; Honoré, 2013; Lenoble et al., 2012; Stouvenot, 2004). Some of the later settlements are cave sites that were mostly visited during the Troumassoid phase, between the 10th and 13th centuries AD (Courtaud et al., 2005, 2014; Grouard et al., 2014; Lenoble et al., 2008; Stouvenot, 

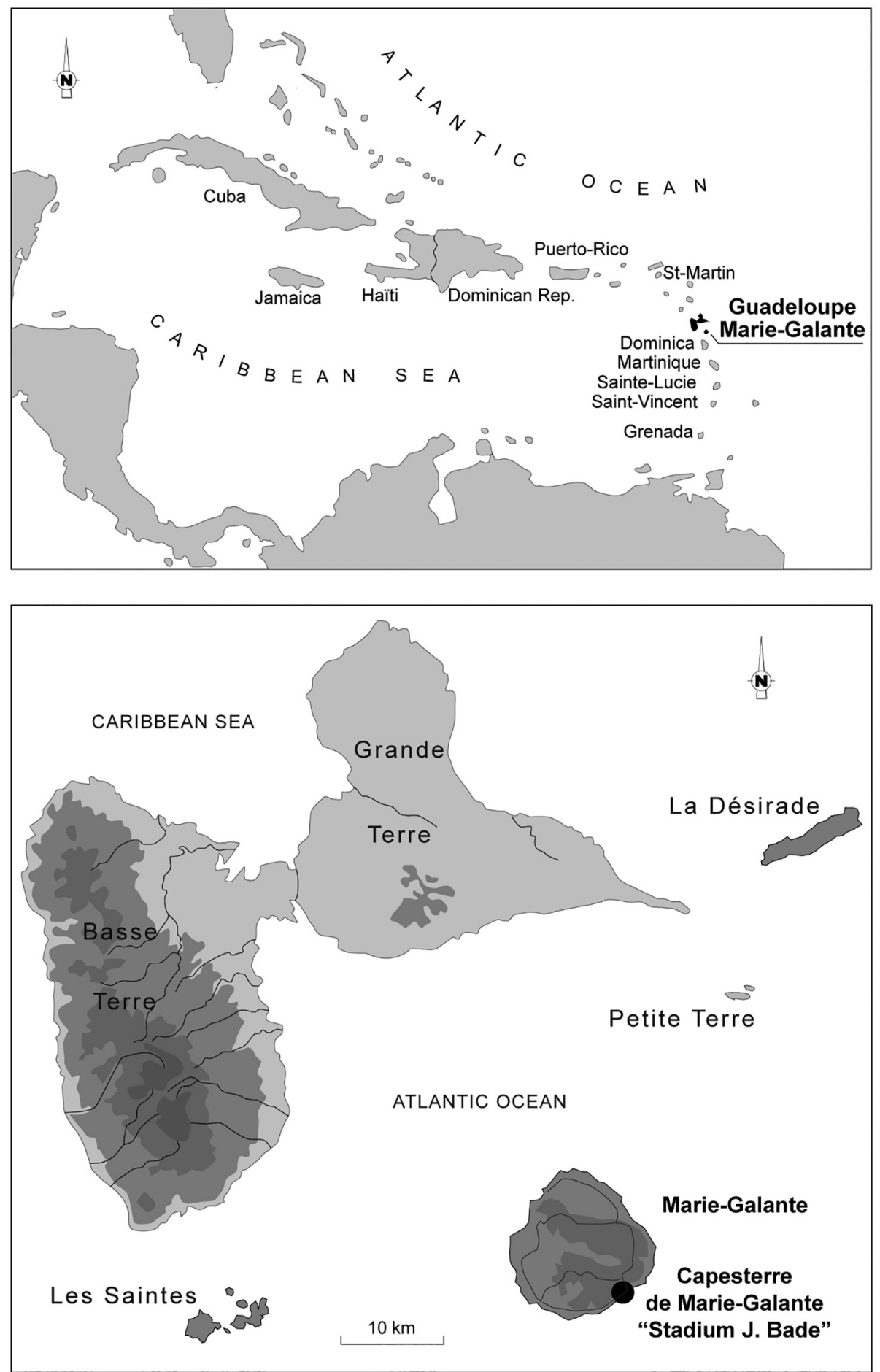

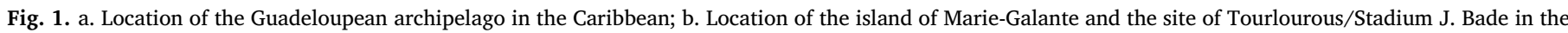
Guadeloupean archipelago (C) N. Serrand, Inrap).

2005; Stouvenot et al., 2014).

The southeastern coast of Marie-Galante near the town of Capesterre de Marie-Galante shows a particular concentration of major pre-Columbian sites, among which is the Tourlourous settlement. This site was discovered by R. Barbotin (1970) in the late 1960s when it was impacted by the building of the Capesterre stadium (Fig. 2). At that time, preventive archaeology procedures were not established. In 2001, new development projects on the western portion of the site gave rise to an archaeological phase I diagnostic investigation (Etrich, 2001) (Fig. 2). That was followed in 2002 by a full phase II excavation carried out by the Institut National de Recherches Archéologiques Préventives (Inrap) on the lower slope of the hill in the northernwestern area, the most impacted zone (Colas, 2003; Colas et al., 2002) (Fig. 2). It revealed parts of a complex settlement with midden areas in use during the late Cedrosan Saladoid period, between the 3rd and 8th centuries AD (cal 237-778 CE), including Troumassoid components in the last centuries.

Ten years later the municipal stadium, adjacent to the east, was subject to new development projects (Fig. 2). Geotechnical tests, surveys and a phase I diagnostic investigation (Fourteau, 2009; Serrand, 

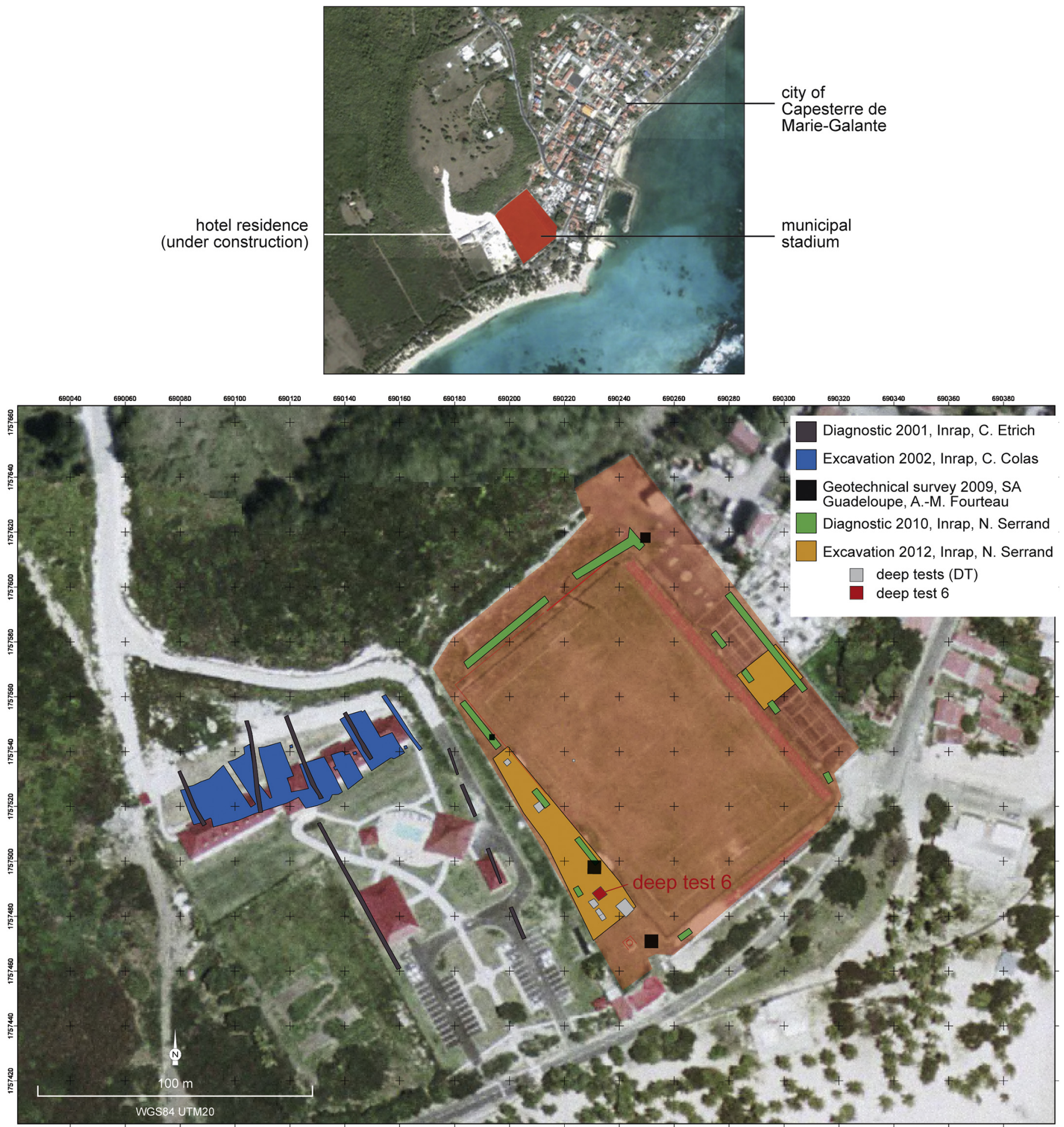

Fig. 2. Map of the archaeological fieldwork carried out at the Tourlourous/Stadium J. Bade site, showing deep pit 6 of the 2012 excavation, where the three-pointer was found (C) C. Stouvenot, DAC, SA Guadeloupe/N. Serrand, Inrap; base: IGN France Geoportail satellite photo). (For interpretation of the references to color, the reader is referred to the web version of this article.)

2010) confirmed that remains of the pre-Columbian Tourlourous settlement extended under the stadium. This led to a new excavation, undertaken by Inrap in 2012 on both sides of the football field (two zones totalling $1273 \mathrm{~m}^{2}$; Serrand et al., 2016a; Serrand et al., 2016b) in order to unearth the site's elements doomed to destruction. The investigation revealed successive Cedrosan Saladoid to Troumassoid village occupation phases lasting from the 3rd to the 13th centuries AD, with a hiatus occurring sometime around the 9th or 10th century.
Particularly rich Troumassoid material was excavated, including a substantial ceramic assemblage of the Mamoran Troumassoid subseries. This material includes six three-pointers, among which is the threepointer that is described and analyzed below.

This artefact was found during the excavation of a deep test pit (DT 6; Fig. 2) that aimed to establish the general stratigraphic framework in area B3 of the site. It comes from stratigraphic unit 3006, the early basal Troumassoid sandy level in area B3 (G31-32), dated elsewhere at 


\section{Zone B - Sector B3}

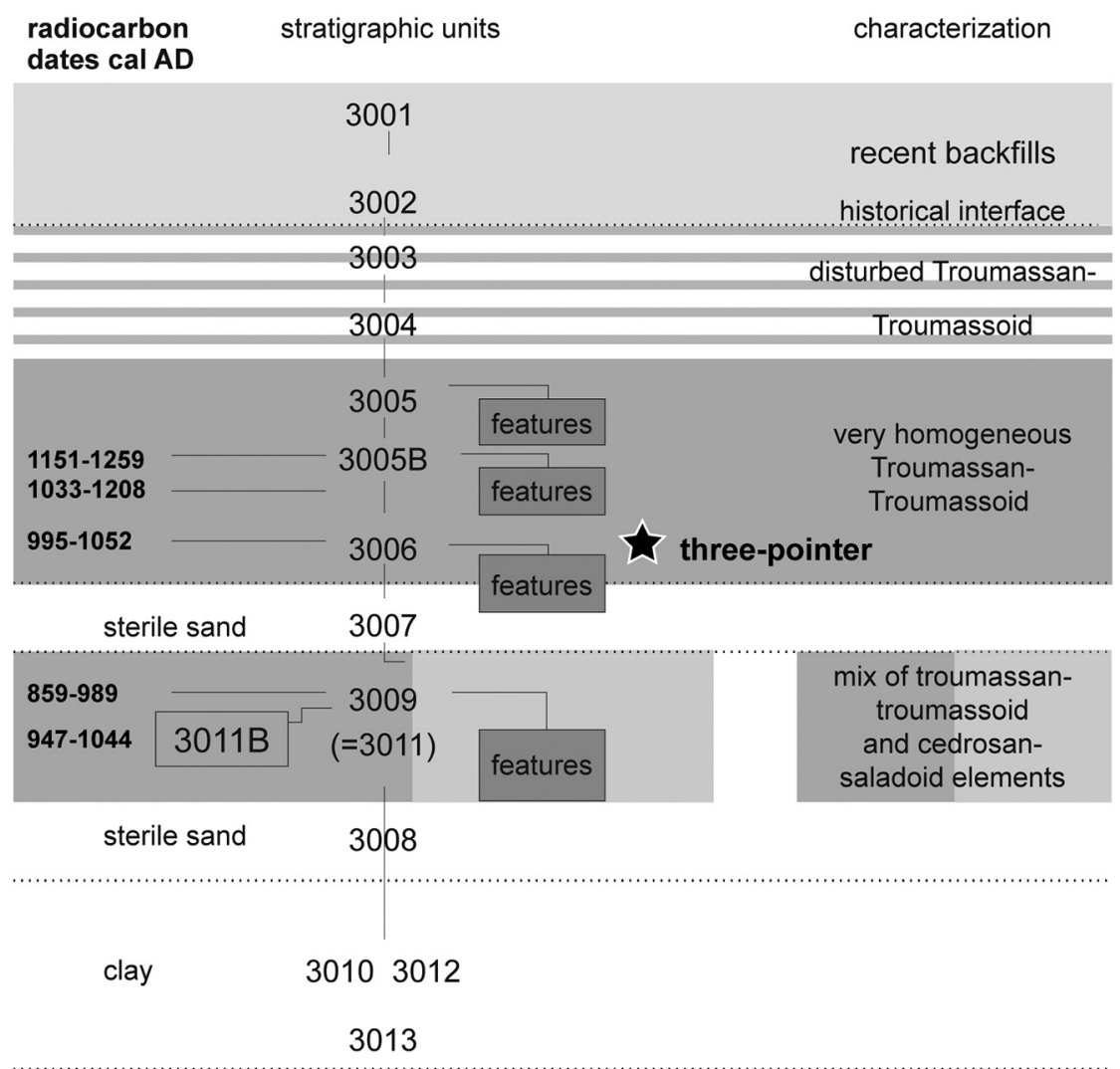

Fig. 3. Stratigraphic chart of sector B3 of the site, with provenience of the Troumassoid three-pointer \# 385 (C) N. Serrand, Inrap).

the site to between the 10th and 11th centuries (Serrand et al., 2016a; Serrand et al., 2016b) (Fig. 3). Unfortunately, it is impossible to assess whether or not it was associated with a feature. The artefact appeared in a slightly moist, light yellow sandy level. It was preserved well enough to exhibit substantial-likely complete-residue of black material in linear configurations on its two basal points (Fig. 4). The artefact, once unearthed, was promptly put into a packaging including sand extracted from the level. It was subsequently neither washed nor treated in any way. It had to be manipulated for photos and extraction of a sample of black material to be analyzed, but handling of the piece was limited as much as possible.

\section{Description of the artefact and the residues}

\subsection{The three-pointer's raw material}

The artefact is made of calcite, a calcium carbonate $\left(\mathrm{CaCO}_{3}\right)$. When pure, this mineral is colorless and transparent, but the fluctuating abundance of cations other than calcium produces a rich array of color variation, these impurities creating a multitude of shades in the mineral's crystals. The reddish and orangey color of the archaeological specimen (Fig. 4) is very likely due to the presence of iron cations. Calcite offers at least 170 known simple forms of xenomorphic or automorphic crystals with perfect cleavages, producing shiny surfaces. The crystals' associations or twins may be adjoining or interpenetrating. The calcite of the archaeological specimen is composed of many crystals, and its twins are polysynthetic. In the Guadeloupean archipelago, this type of rock can be found in the limestone that composes the upper terraces of Grande-Terre and of the island of Marie-Galante.

The raw calcite used for producing the three-pointer could have been found either as a seam or breccia filling deposit or as a fragment of a speleothem or of a stalagmite floor in a karstic cavity. Samples of seam or breccia filling calcite from Grande-Terre (Saint-François, AnseBertrand) are shown in Fig. 5a; they were found in the substratum among limestone blocks, and their crystalline amalgam is coated with chalky limestone. This calcite formation has a smoky aspect, exhibiting polysynthetic twins and centimetric crystals. The volume of calcite (120x70x70 mm) of this sample alone would have been enough for producing a three-pointer similar to the studied archaeological artefact (87x51x50 mm).

It is also possible, however, that the calcite used for the archaeological three-pointer derived from a fragment of a speleothem or a stalagmite floor of a karstic cavity (Fig. 5b). Such cavities are numerous in the limestone regions of Guadeloupe (Grande-Terre, Marie-Galante, Désirade) and in islands to the north (Saint-Martin, Saint-Barthélemy). Blocks of pure calcite, sometimes larger than a cubic meter, can be found where they have fallen from cave entrances or ceilings, or where they have broken from stalactites and stalagmites. It is to be noted that the Morne Rita cave on the island of Marie-Galante, which is a site where several speleothems are adorned with pre-Columbian Amerindian engraved figures (Fouéré et al., 2014), is only $3 \mathrm{~km}$ east of the site of Tourlourous/Stadium J. Bade where the three-pointer was found. Of note as well is the close proximity $(2 \mathrm{~km})$ of a limestone cliff with other caves and rock-shelters, which were all visited during pre-Columbian, especially Troumassoid, times (i.e., Blanchard 1 and 2, Cadet 1, 2, and 3; see Grouard et al., 2014).

The hardness of calcite only reaches 3 on the 10-level Mohs scale. For comparison, other lithic materials commonly used by the preColumbian Amerindians for producing tools, such as quartz, jasper or flint, reach 7 on that scale. Calcite is thus rather easy to work and lends itself to the production of sculptures. 

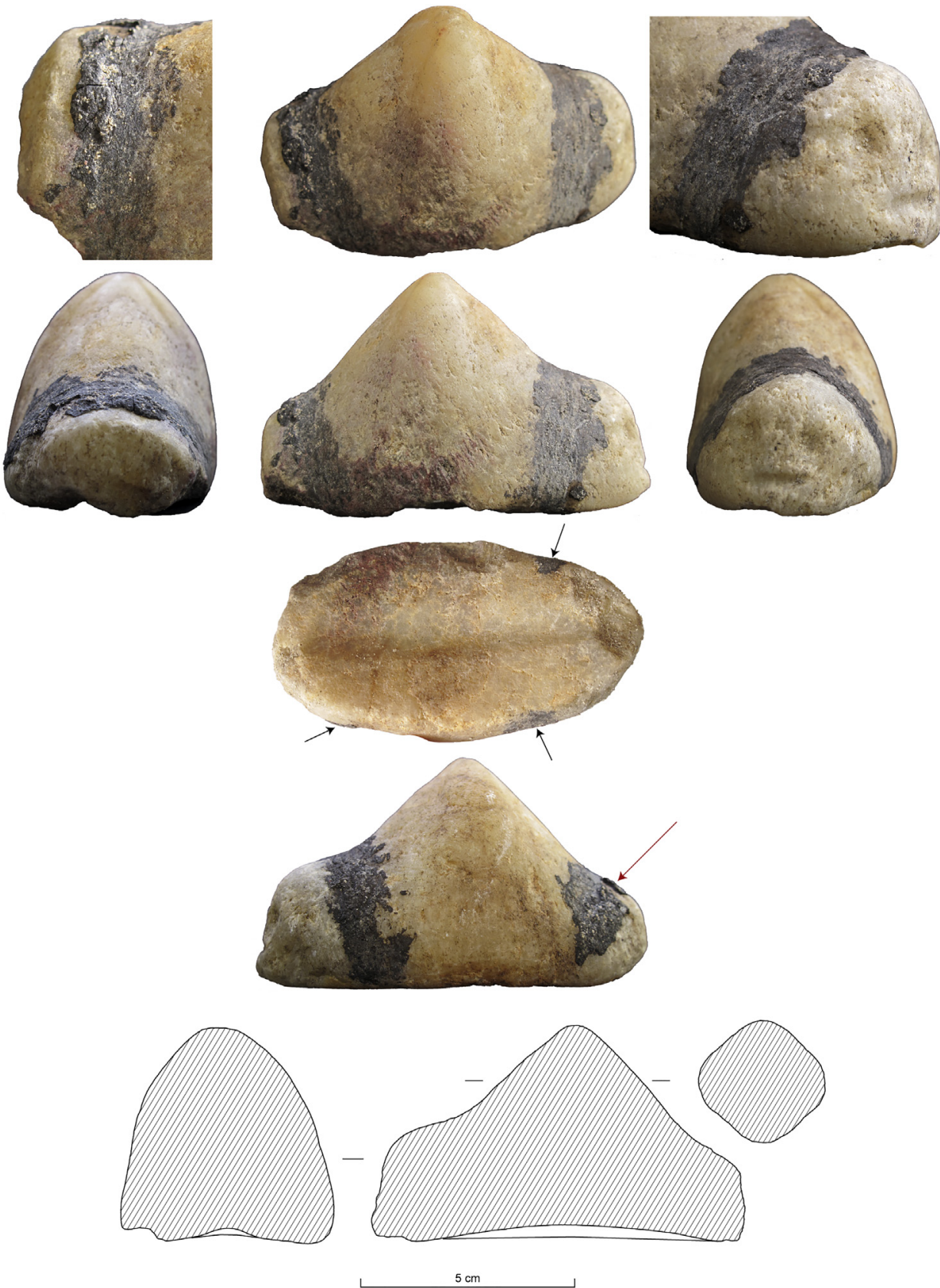

Fig. 4. Views of the Troumassoid calcite three-pointer \# 385; red arrow points to the sample's location, black arrows point to locations where black residue stops at the edge of the basal surface (length: $89 \mathrm{~mm}$; width: $50 \mathrm{~mm}$; height: $50 \mathrm{~mm}$; weight: $244 \mathrm{~g}$ ); profile and section drawing of the Troumassoid three-pointer \# 385 (photos by N. Serrand, Inrap; drawings by F. Casagrande, Inrap). (For interpretation of the references to color in this figure legend, the reader is referred to the web version of this article.)

\subsection{The three-pointer's manufacturing traces}

The studied three-pointer's dimensions are 87 (length) $\times 51$ (width) $\times 50 \mathrm{~mm}$ (height). The object is characterized by lateral bulges on the apical point and a human-like face on one of the basal points (Figs. 4, 6, 8). Some details suggest the object was produced in several stages.

The surface of this calcite three-pointer is rather matt (Fig. 4). Indeed, the material did not seem to lend itself to a thorough, perfect and smooth polishing. In places, fine striations that are more or less parallel and aligned vertically according to the piece's vertical axis are visible to the naked eye (Fig. 6). Such marks may have been produced by abrasive tools made out of materials such as pumice stone, beach rock and the like. Deeper streaks seem to delimit the bulges visible on the sides of the upper point (Fig. 4), a quite intriguing attribute of the artefact. These bulges may have been made to reinforce that apical part. The finishing of the two basal points and of their surfaces is less advanced. In fact, chips produced during the shaping of these points are still clearly visible on their inferior faces (Fig. 4). It seems that the whole piece was once ground and slightly polished, including the two basal points, and that these latter were subsequently truncated, at some point during the object's lifetime. Their surfaces were then more or less reworked; one of them was adorned with a simple face, represented only with a straight mouth engraved by means of a sawing motion and two eyes produced by pecking (Figs. 4, 6).

Another calcite three-pointer, fortuitously recovered from MarieGalante (Fig. 7), from a place known as Saint-Germain with no context or chronological data, shows very close similarities. Its shaping does not 

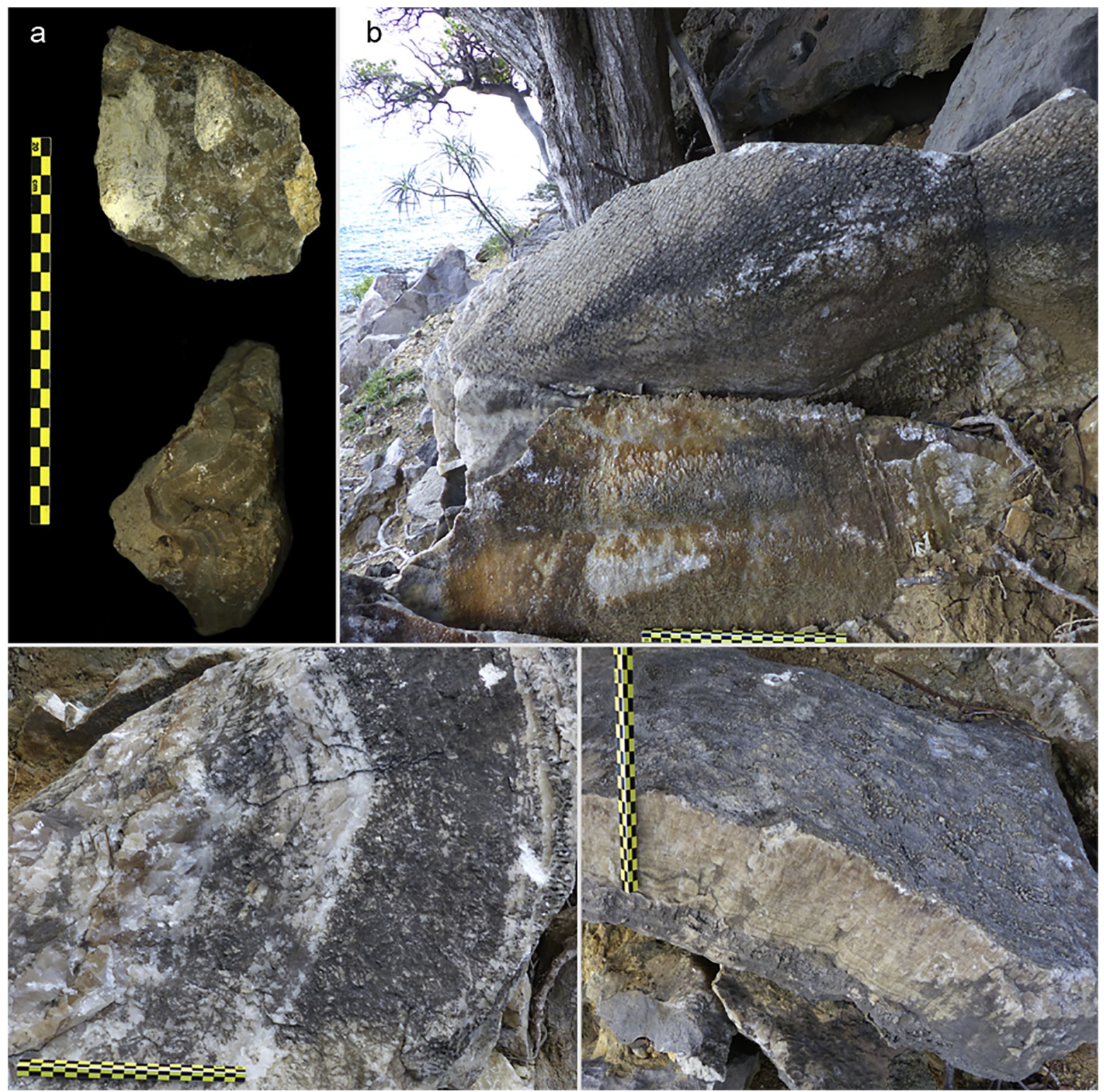

Fig. 5. a. Calcite samples from seam or breccia filling found in the substratum in Saint-François and Anse-Bertrand, Grande-Terre of Guadeloupe (photos by F. Casagrande, Inrap); b. Views of calcite blocks near the Grotte Montbars in Saint-Barthélemy (photos by N. Serrand, Inrap). (For interpretation of the references to color in this figure legend, the reader is referred to the web version of this article.)

seem to include several stages, but it exhibits a very comparable general shape, a slightly curved base and a crude face. These two Marie-Galante three-pointers show similarities with other specimens that Boomert (2000: 488) describes as having "crudely incised anthropomorphic face designs at one end of the artefact." Such pieces, found in the Late Saladoid Maisabel site in Puerto Rico (Siegel, 1992: 102, 411-412) and in Late Saladoid/Troumassoid contexts in Guadeloupe (Breukel, 2013), are seen by Boomert (2000: 488) as an indication of a process of anthropomorphisation of stone three-pointers in late Saladoid and early Troumassoid times.

\subsection{The black residues}

Residues of black material are present, quite well preserved, on the upper surfaces of both basal projections of the specimen (Fig. 4); they have a thickness of approximately $4-5 \mathrm{~mm}$. Thorough examination did not reveal any residue or hint of such material on any surface of the apical point of the artefact. As for the basal surface, it is not covered with the material, as only three slightly projecting spots can be observed (Fig. 4, black arrows). They originate from the non-basal surface and end at the edge of the basal worked surface, which has been abraded in order to produce a slight central groove. Thorough examination suggests that no black material ever covered the surface of the base. The residues on both basal points show concentric grooves imprinted in the black material (Fig. 8).

Among the 6 three-pointers found at the site, two also show traces of black material. One (\#359) was associated with a posthole fill dated to the Troumassoid phase of occupation (area B2, feature 38). It is made of reef limestone and exhibits specks of black residue, which are limited to small bits trapped in the limestone's irregularities (Fig. 9). Examination revealed remnants of once larger spots of black material on the base's lower surface and on the back of at least one of the basal points (Fig. 9). The other one (\#107) is a fragment of a point found in an earlier Cedrosan Saladoid context with Troumassoid components. It exhibits a few very faint traces on the surface of its base. The three others-one from a Cedrosan Saladoid context and two others from a Troumassoid 


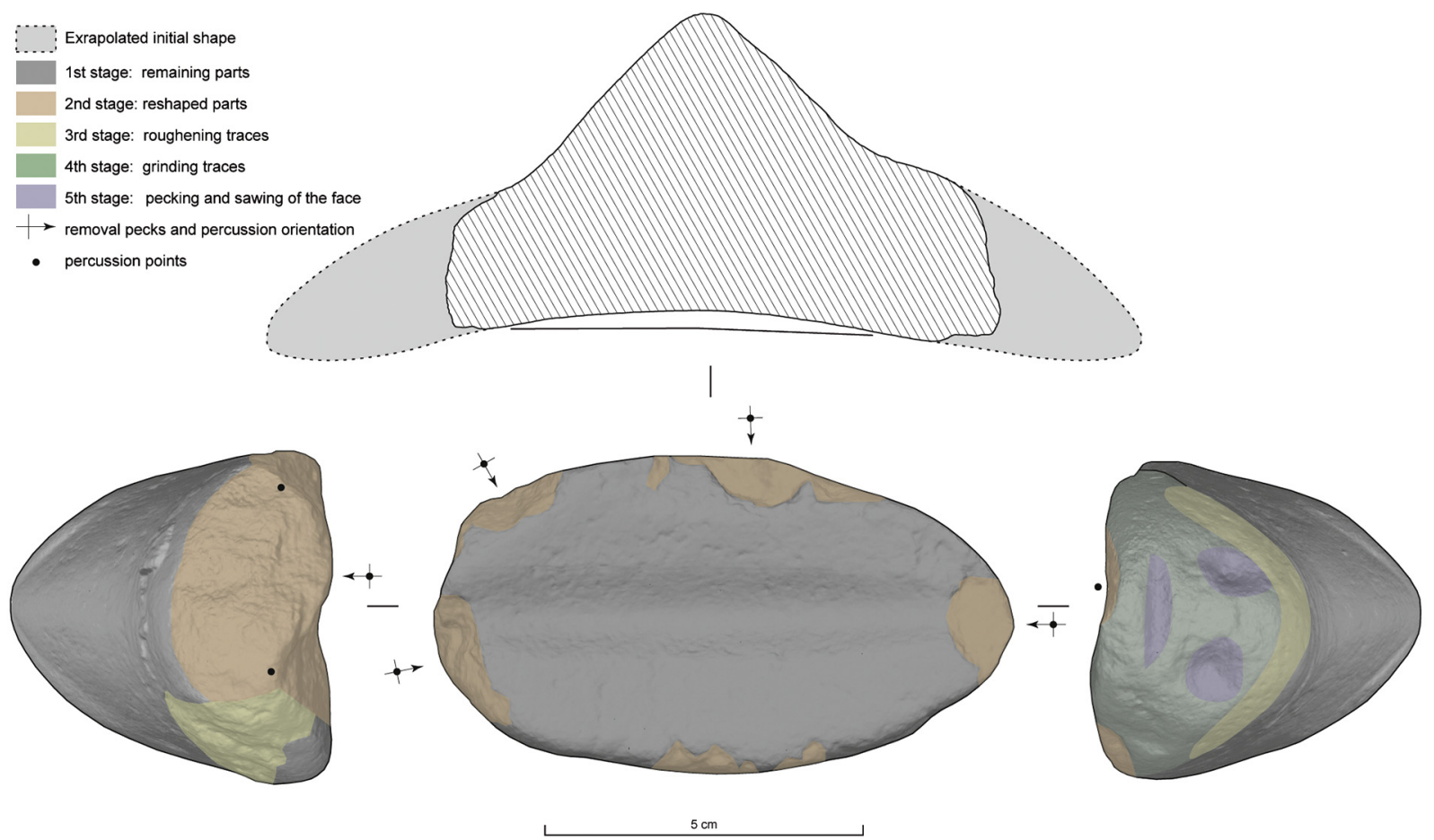

Fig. 6. Explanatory diagram of the successive technological stages readable on the three-pointer \# 385 (drawings by F. Casagrande, Inrap).

context-do not exhibit any black residues. This does not exclude the possibility that residues were present but were not preserved.

\section{Physico-chemical analysis of the residue}

\subsection{Sample}

Handling of the three-pointer \#385 was limited as much as possible, and it was only manipulated for photos. During that procedure, a bit of the black material fell. It was saved as the sample to be analyzed (Fig. 4, red arrow). It was estimated as weighing $50 \mathrm{mg}$ and was processed in two fractions.

\subsection{Reagents}

All solvents were HPLC grade (Sigma Aldrich, Milan, Italy).

\subsection{Sample preparation, cleanup and fractionation}

Two different analytical procedures for the characterization of organic materials, both based on gas chromatography/mass spectrometry (GC/MS) analyses, were used on two different aliquots of the sample.
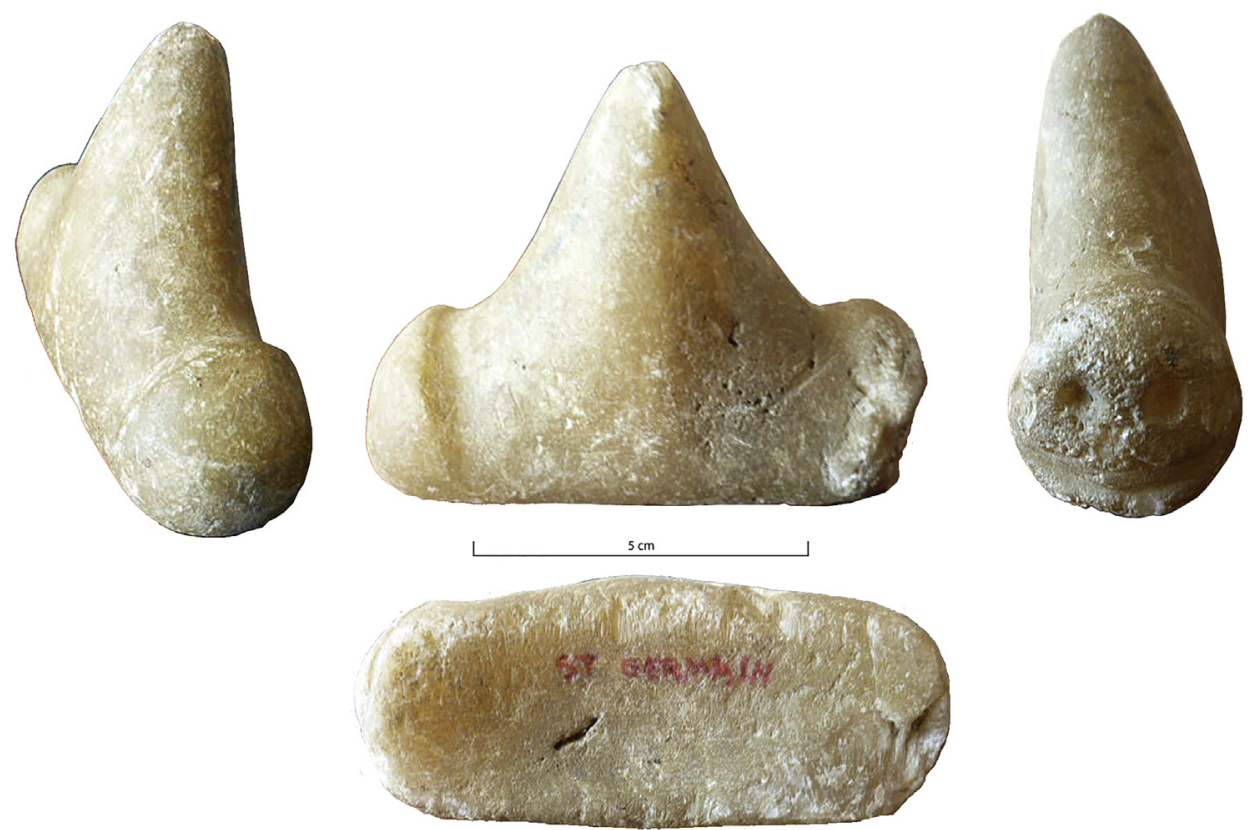

Fig. 7. Three-pointer specimen from Saint-Germain, Marie-Galante, Guadeloupe; MEC-I-17.3.1-collections of the E. Clerc Museum, Department of Guadeloupe, Le Moule (@ photos by S. Guimaraes). (For interpretation of the references to color, the reader is referred to the web version of this article.) 

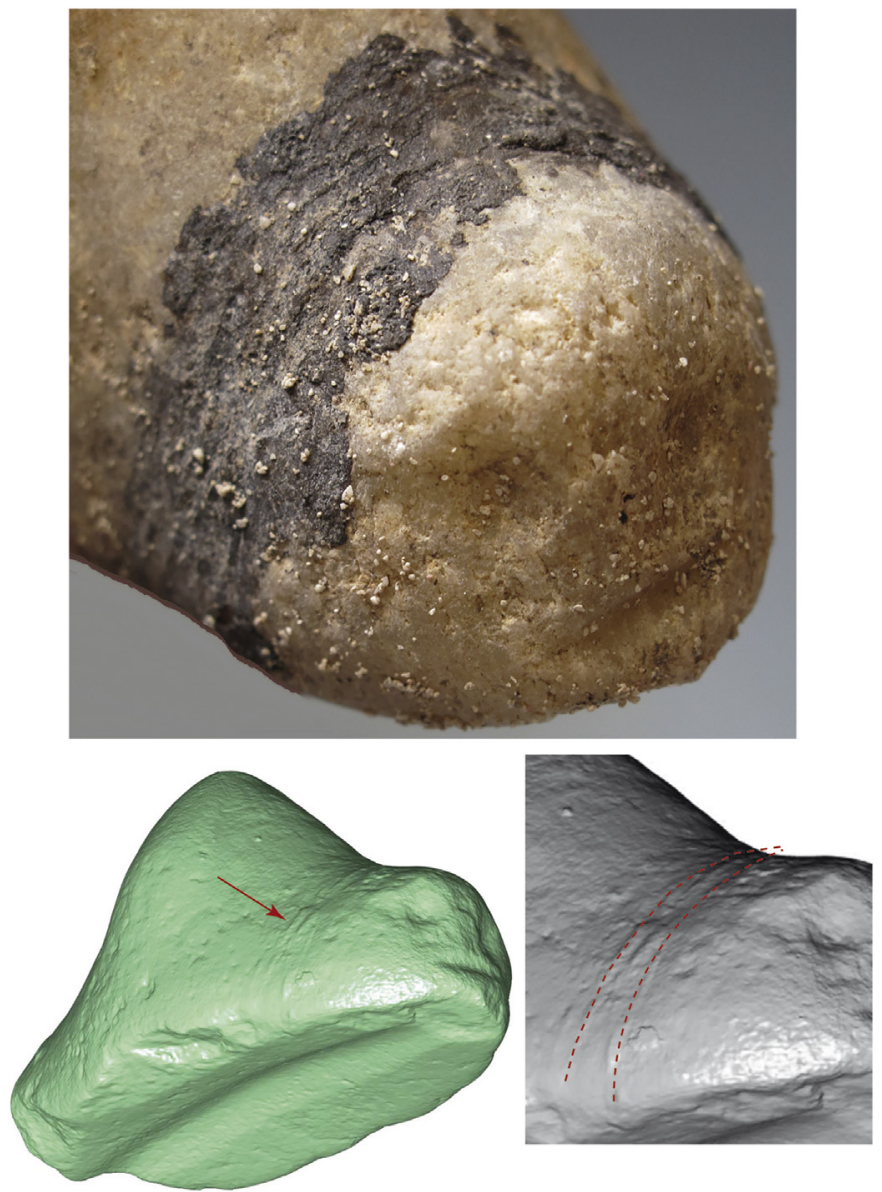

Fig. 8. Upper: details of the face and the black residues on the Troumassoid three-pointer \# 385, showing imprints in the residues (photo by N. Serrand, Inrap); Lower: 3D images showing the concentric linear grooves tentatively interpreted as imprints from ligatures (indicated by the red arrow and dashed lines; photo and 3D image by F. Casagrande, Inrap). (For interpretation of the references to color in this figure legend, the reader is referred to the web version of this article.)

The first fraction of the sample $(5.4 \mathrm{mg})$ was subjected to an analytical procedure for the determination of proteinaceous materials (animal glue, milk or casein, egg, garlic), polysaccharide materials (starch, tragacanth gum, Arabic gum, fruit tree gum, guar gum, karaya gum), glycerolipids (linseed oil, walnut oil, poppy seed oil, egg), natural waxes (beeswax, Carbauba wax), plant resins (Pinaceae resin, mastic, dammar, sandarac) and animal resins (shellac). A description of the analytical procedure as well as all the instrumental conditions are reported in Lluveras et al. (2010).

The second fraction of the same sample $(2.1 \mathrm{mg}$ of powder) was extracted ultrasonically with $1: 1(\mathrm{w} / \mathrm{w}) \mathrm{n}$-hexane/dichloromethane (DCM) $400 \mu \mathrm{L}$ for $30 \mathrm{~min}$, and then with DCM alone ( $400 \mu \mathrm{L}$ for $15 \mathrm{~min}$ for two times) in order to identify free alkanes and aromatic or polar compounds of bituminous materials (Connan, 1988; Connan et al., 1990; Lucejko et al., 2017). The asphaltenes were precipitated with nhexane, and the deasphalted bitumens were subsequently fractionated into alkanes and aromatic compounds using a silica gel chromatographic column. The alkanes were eluted with $4 \mathrm{~mL}$ of $\mathrm{n}$-hexane, while the aromatic fraction was eluted with $2-3 \mathrm{~mL}$ of $\mathrm{n}$-hexane/DCM (1:1). Then they were separated and analyzed by GC/MS.

\subsection{Gas chromatography/mass spectrometry (GC/MS)}

GC/MS analyses of alkanes and aromatic compounds were performed using a $6890 \mathrm{~N}$ Network GC System (Agilent Technologies, Palo
Alto, CA, USA) equipped with a split/split less injection port and coupled to a 5973 MS detector with a quadrupole analyzer. Samples were injected in split less mode at $280^{\circ} \mathrm{C}$. GC separation was performed on a fused silica capillary column HP-5MS (J\&W Scientific, Agilent Technologies, stationary phase 5\% diphenyl-95\% dimethyl-polysiloxane, $30 \mathrm{~m}, 0.25 \mathrm{~mm}$ i.d., $0.25 \mu \mathrm{m}$ film thickness) connected to a deactivated fused silica pre-column (J\&W Scientific, Agilent Technologies, $2 \mathrm{~m}, 0.32 \mathrm{~mm}$ i.d.).

The compounds were separated applying the following chromatographic conditions: temperature program from $80^{\circ} \mathrm{C}$ to $280^{\circ} \mathrm{C}(2 \mathrm{~min}$ isothermal at $80^{\circ} \mathrm{C}$, then $10^{\circ} \mathrm{C} \mathrm{min}^{-1}$ up to $150^{\circ} \mathrm{C}, 3 \mathrm{~min}$ isothermal at $150^{\circ} \mathrm{C}$ and then $4^{\circ} \mathrm{C} \mathrm{min}{ }^{-1}$ up to $280^{\circ} \mathrm{C}, 60 \mathrm{~min}$ isothermal at $280^{\circ} \mathrm{C}$ ) and helium gas flow as the carrier gas $\left(1.2 \mathrm{~mL} \mathrm{~min}^{-1}\right.$; purity 99.9995\%). MS parameters were: electron impact ionization (EI, $70 \mathrm{eV}$ ) in positive mode, ion source temperature $230^{\circ} \mathrm{C}$, interface temperature $280^{\circ} \mathrm{C}$. The chromatograms were obtained in total ion current (TIC, mass scan range $m / z 50-700$ ) and in selected ion monitoring (SIM, $m / z$ 191, 217, 231 and 253). Peaks assignments were performed using mass spectra interpretation, comparisons with mass spectral libraries (NIST 2.0), and published data (Connan, 1999; Wang et al., 2006).

\subsection{Results}

The sample showed the absence of proteinaceous, lipid, resinous and saccharide materials. On the other hand, bituminous material was indicated by the occurrence of specific compounds such as steranes and terpanes. Fig. 10 shows the general molecular structures of these two classes of compounds. Fig. 11 shows the extracted ion gas chromatograms obtained in the analysis of the black material collected from the three-pointer.

The GC/MS results indicate that the archaeological sample from Guadeloupe contains n-alkanes, in which the main compounds are steranes $(m / z 217)$, followed by terpanes $(m / z 191)$. Table 1 provides a list of the compounds found in the sample and characteristic of a bituminous material. The aromatic steranes, such as triaromatic $m / z 231$ and monoaromatic $m / z 253$, are absent in the archaeological sample.

The sample shows a high degree of demethylation of terpane compounds, such as 22,28,29,30-tetrakisnorhopane, $\mathrm{C}_{30}$ 28-norhopane, and $17 \alpha(\mathrm{H})$-30-nor-29-homohopane, which may indicate a high degree of maturation of the sample (Jacquot et al., 1996; Hostettler et al., 2000). In any case, chemical degradation due to human actions, such as heating, could not be excluded.

\section{Discussion}

\subsection{Use of bitumen and other coating material at the Tourlourous site}

The Tourlourous/Stadium J. Bade settlement thus yielded three three-pointers showing residues of black material, one of which has been demonstrated as bitumen. The preparation of bitumen and manufacturing of at least some adhesive-coated objects at the site are suggested by an additional item. Black residue found on the interior surface of a belly shard of a large vessel from a Troumassoid level with residual Cedrosan Saladoid components (area A - square S25 - us 2516) (Fig. 12), thought to be organic charred material, was sampled for radiocarbon dating. Unexpectedly, the result returned a date of $31,843 \pm 464$ BP (UBA22195, Chrono Center laboratory, Belfast), that is, in calibrated years, 35,399-33,143 cal BC (2 sigmas, 95.4\%). No other such extremely inconsistent date was obtained for the site, and most dated materials (charred residues, charcoal and shells) returned coherent results. It thus appears that the dated material from this shard could be bitumen with a Pleistocene age. Thus, this shard with attached residues of probable bitumen likely attests to the preparation of such material at the site, possibly by heating, as suggested by the chemical analyses performed on the three-pointer's bitumen residue.

This small set of artefacts, among which one has been demonstrated 

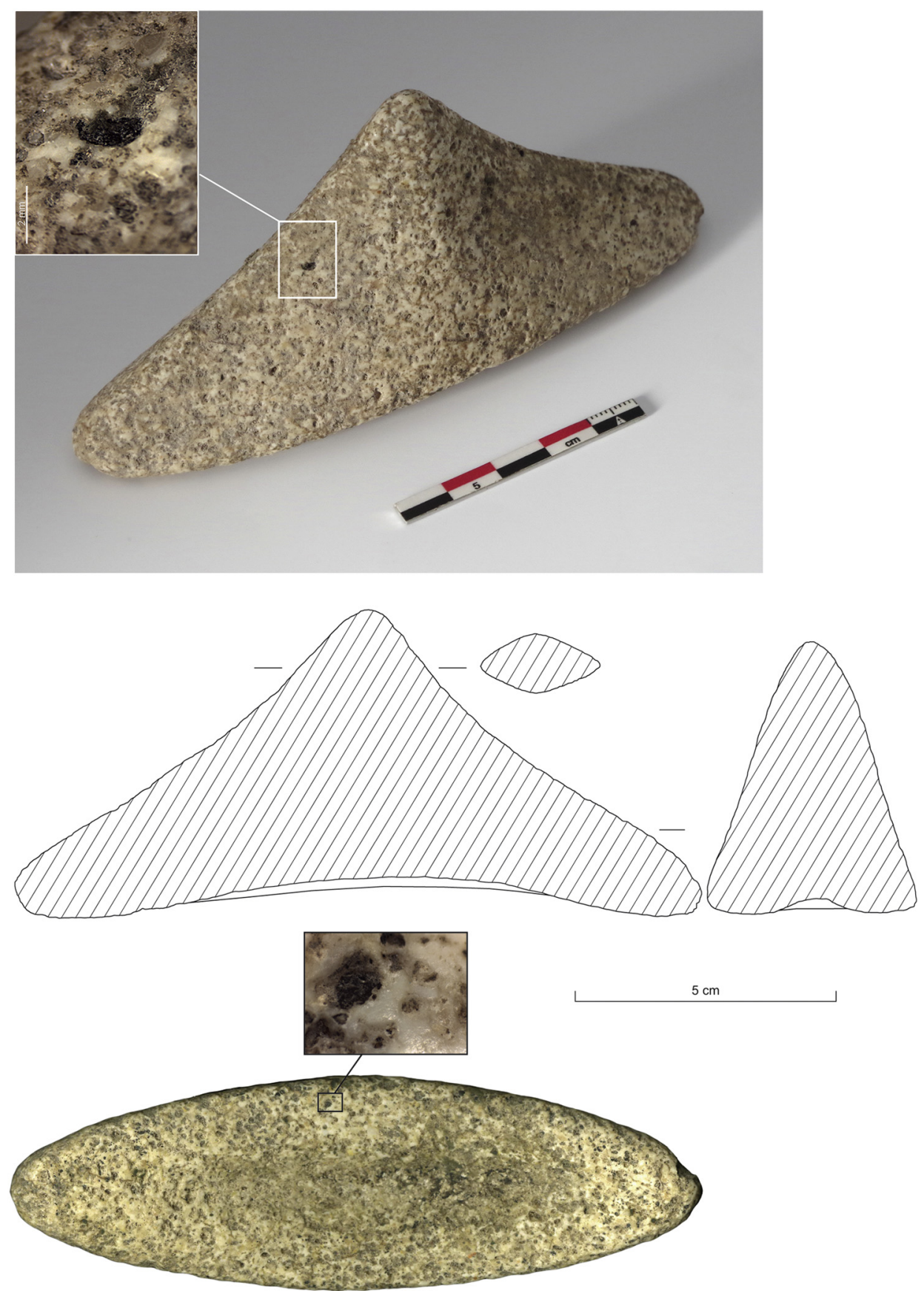

Fig. 9. Photographs and drawings of the Troumassoid reef limestone three-pointer \# 359, showing only traces of residues on its back and base (length: $132 \mathrm{~mm}$; width: $42 \mathrm{~mm}$; height: $59 \mathrm{~mm}$; weight: $196 \mathrm{~g}$; photos and drawings by F. Casagrande, Inrap). (For interpretation of the references to color in this figure legend, the reader is referred to the web version of this article.)<smiles>CC(C)C1CC[C@]2(C)C1CC[C@@]1(C)C2CCC2C3(C)CCCC(C)(C)C3CCC21C</smiles><smiles>CCC(CCC(C)C1CCC2C3CCC4CCCCC4(C)C3CCC12C)C(C)C</smiles>

Fig. 10. Molecular structures of representative alkane compounds in bitumen (hopane $m / z 191$ and steranes $m / z$ 217) (C S. Orsini, E. Ribechini). 


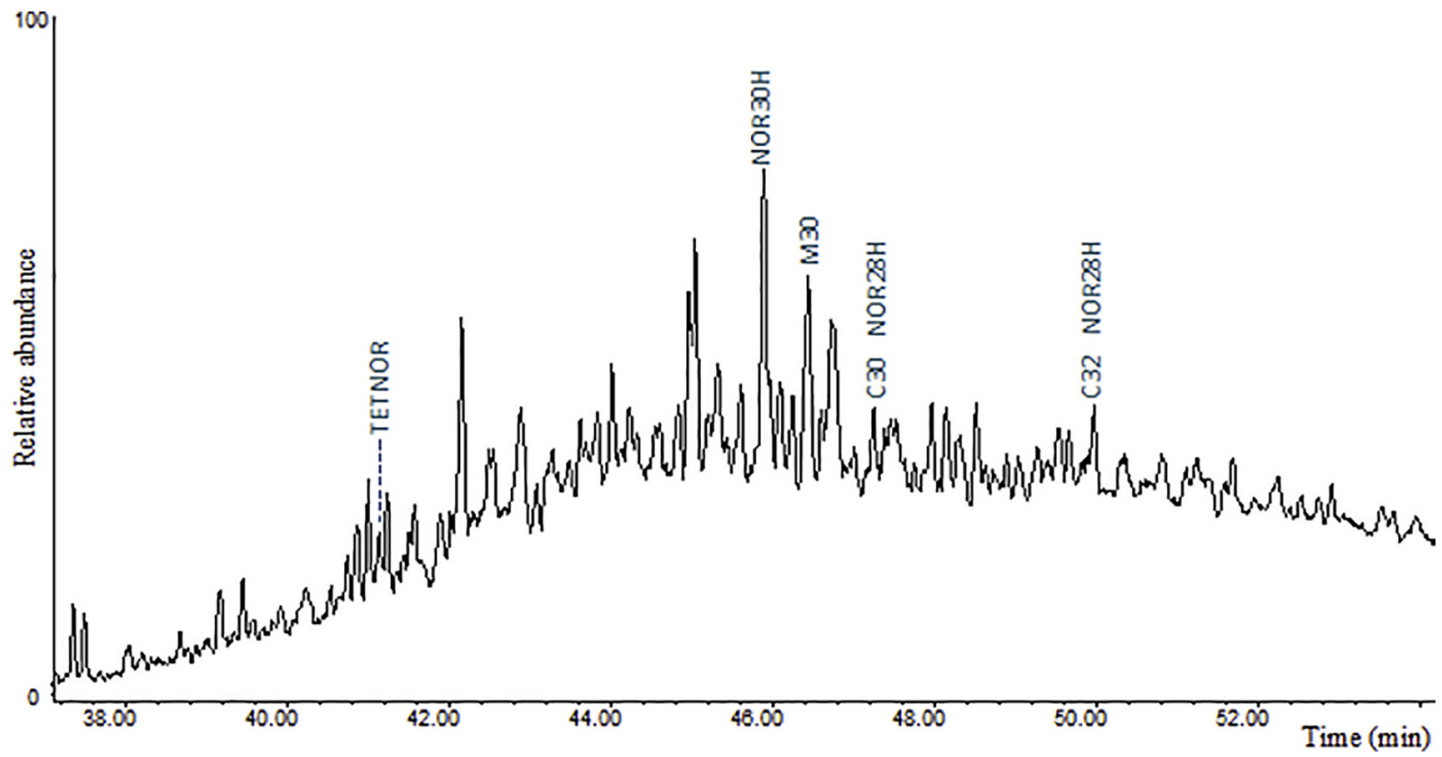

Fig. 11. Chromatogram in Total Ion Current TIC $(\mathrm{m} / \mathrm{z} 191)$ of the alkanes in the sample extracted from the Troumassoid three-pointer \# 385 (C) S. Orsini, E. Ribechini).

Table 1

Bitumen terpane and sterane biomarkers found in the sample collected from the three-pointer.

\begin{tabular}{|c|c|c|}
\hline Compound of bitumen & Code & Archaeological Sample \\
\hline \multicolumn{3}{|l|}{ Terpanes $m / z 191$} \\
\hline 22,28,29,30-tetrakisnorhopane & TETNOR & $\mathrm{x}$ \\
\hline $\mathrm{C}_{30}$ 28-norhopane & C30NOR28 & $\mathrm{x}$ \\
\hline $17 \alpha(\mathrm{H})$-30-nor-29-homohopane & NOR3OH & $\mathrm{x}$ \\
\hline $17 \beta(\mathrm{H}), 21 \alpha(\mathrm{H})$ - hopane & M30 & $\mathrm{x}$ \\
\hline $\mathrm{C}_{32}$ 28-norhopane & C32NOR28 & $\mathrm{x}$ \\
\hline \multicolumn{3}{|l|}{ Steranes $m / z 217$} \\
\hline $\begin{array}{l}\mathrm{C}_{29} 20 \mathrm{~S}-5 \alpha(\mathrm{H}), 14 \alpha(\mathrm{H}), 17 \alpha(\mathrm{H})- \\
\text { stigmastane }\end{array}$ & C29S & $\mathrm{x}$ \\
\hline $\begin{array}{l}\mathrm{C}_{29} 20 \mathrm{R}-5 \alpha(\mathrm{H}), 14 \beta(\mathrm{H}), 17 \beta(\mathrm{H})- \\
\text { stigmastane }\end{array}$ & $C 29 \beta \beta R$ & $\mathrm{x}$ \\
\hline $\begin{array}{l}\mathrm{C}_{29} 20 \mathrm{~S}-5 \alpha(\mathrm{H}), 14 \beta(\mathrm{H}), 17 \beta(\mathrm{H})- \\
\text { stigmastane }\end{array}$ & C29ßßS & $\mathrm{x}$ \\
\hline $\begin{array}{l}\mathrm{C}_{29} 20 \mathrm{R}-5 \alpha(\mathrm{H}), 14 \alpha(\mathrm{H}), 17 \alpha(\mathrm{H})- \\
\text { stigmastane }\end{array}$ & C29R & $\mathrm{x}$ \\
\hline $\mathrm{C}_{30}$ steranes & C30s & $\mathrm{x}$ \\
\hline
\end{tabular}

to be coated with bitumen and another yields clues of bitumen preparation or storage in a ceramic vessel, raises the possibility that this material may have been used in a variety of contexts at the site. The last artefact with remnants of black material is a roughly shaped shell disk, probably made from queen conch Lobatus gigas (Fig. 13). Residues occur both on its convex, irregular, outer natural face and on parts of its edges. The concave, inner natural side shows no trace of such black material. Similar objects found in pre-Columbian contexts are believed to have been inlays (Alegría, 1981) in objects such as wooden statues, duhos, masks and other items, implying the use of some sort of adhesive coating. Nevertheless, most of these coating materials have been demonstrated to be plant extracted resins (Ostapkowicz et al., 2011, 2012, 2013), bitumen not being often described or retrieved.

A line of inquiry and research should thus be to investigate the conditions for selection of either bitumen or botanical adhesives. For example, bitumen may have been reserved for specific heavy artefacts, implying ligature systems to secure the tie. Plant gums and resins may have been preferred for lighter items such as inlays.
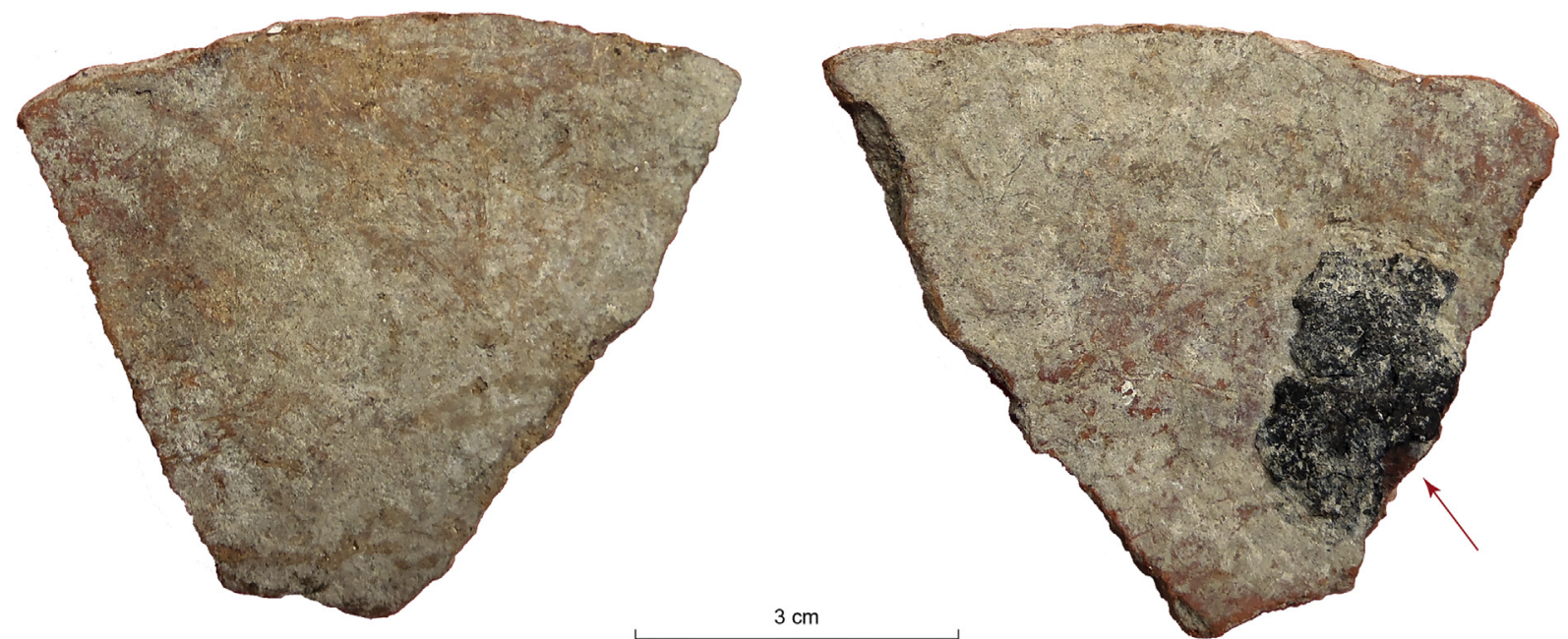

Fig. 12. Views of a Troumassoid ceramic shard (part of a large pot) showing a patch of black material on its interior surface (photos by N. Serrand, Inrap). (For interpretation of the references to color in this figure legend, the reader is referred to the web version of this article.) 


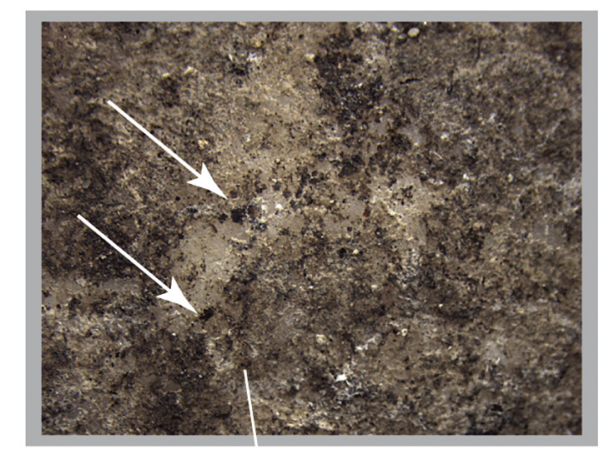

L $2 \mathrm{~cm}$
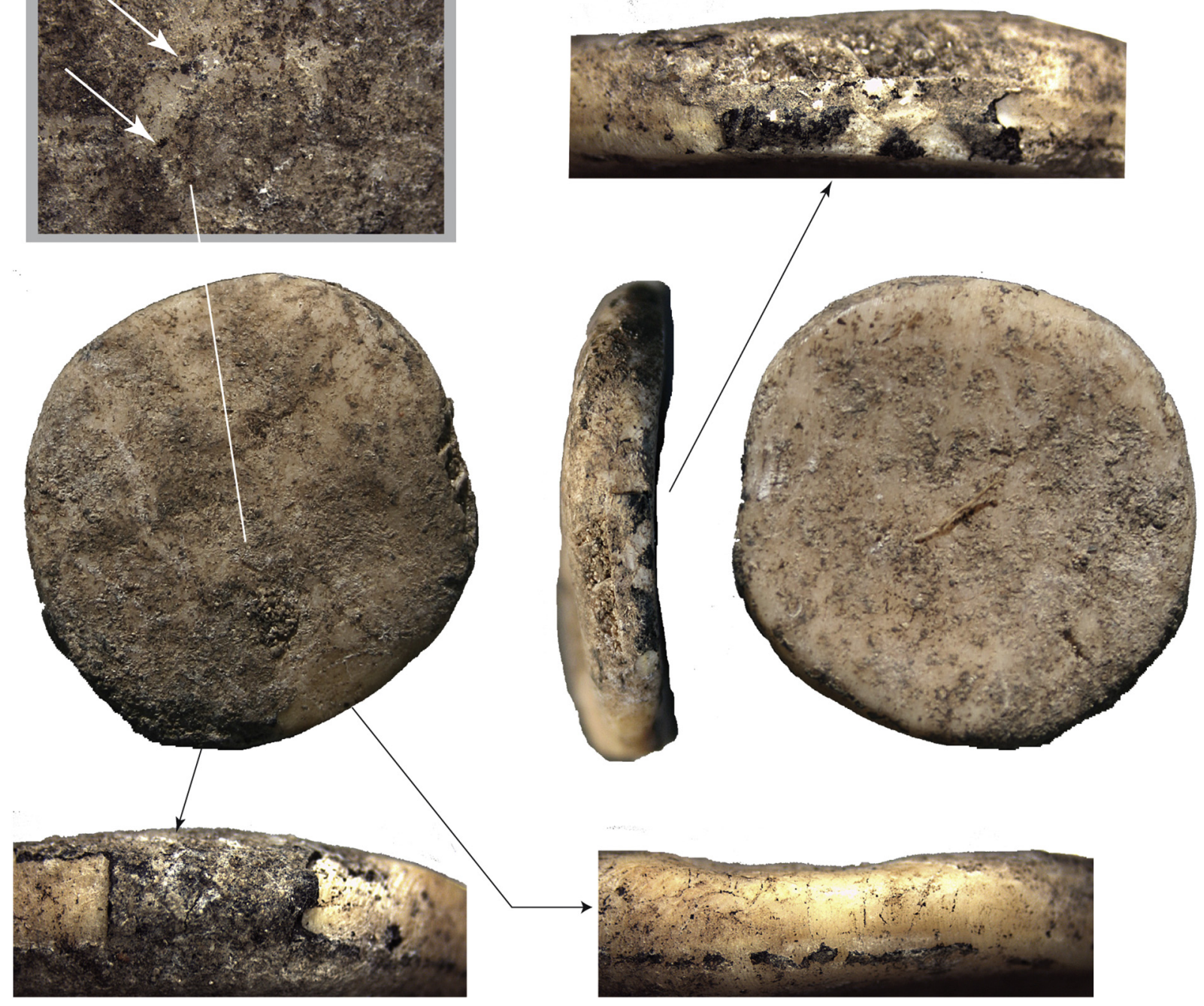

Fig. 13. Views of a Troumassoid unperforated shell disk showing residual traces of black material (red arrows) on one face and the outer edge (maximum diameter: $23.9 \mathrm{~mm}$; minimum diameter: $23.7 \mathrm{~mm}$; thickness: $3.9 \mathrm{~mm}$; weight: $4 \mathrm{~g}$; photos by $\mathrm{N}$. Serrand, Inrap). (For interpretation of the references to color in this figure legend, the reader is referred to the web version of this article.)

\subsection{Possible origins of bitumen in the Lesser Antilles}

Geological bitumen (asphalt, pitch or tar) is a naturally occurring petroleum product chemically made up of a mixture of complex natural hydrocarbons and oxidized products. It can have a solid or liquid state and a brownish or blackish color. It is liquefiable with heat and adheres to various supports.

Bitumen can occur naturally in isolated phanerozoic strata in seepages, seeps, wells or "lakes." Bitumen pellets can also be extracted from such strata by the action of seawater, drift and then be washed ashore in various places (Roehl, 1993). The largest bitumen seep in the Caribbean, the "Pitch Lake" of southwest Trinidad ( $5 \mathrm{~km}$ in diameter) was known by the Amerindians (who called it Piche), at least during the XVIth century (Raleigh, 1887 [1595]) and undoubtedly before. Indeed, a multi-component site with a Saladoid occupation is located on the margins of the lake (Boomert, 2000). Nevertheless, many other smaller deposits of asphalt are also scattered over the island of Trinidad (Richardson, 1917). Another pitch lake, the Bermudez Lake, is located on the mainland some 65 miles inland from the Orinoco River's mouth (Venezuela). That region is part of the wide cultural area in which Amerindian island populations had close connections and maintained intense trade systems (Serrand and Cummings, 2014).

The material used on the Tourlourous three-pointer includes a fair quantity of isolated inorganic grains of crystal or quartz (Fig. 14). It could either indicate that the raw bitumen was picked up ashore after weathering and integration of exogenous material or, whatever its origin, that it was mixed with mineral additives so as to get it to stiffen upon application (see Connan, 1999).

The chemical composition of the bitumen found on the Tourlourous three-pointer was compared with the composition of a bitumen sample from the Trinidad pitch lake (thanks to J. G. Crock). The different distribution of the compounds in the two bitumen samples seems to exclude that the archaeological sample could come from Trinidad. In particular, the archaeological bitumen, showing a high degree of demethylation of terpane compounds, seems to have a higher degree of maturation. In any case, a chemical degradation due to human actions, such as heating, or to burial conditions could not be excluded. Thus, at present it has not been possible to identify the origin of the bitumen used on the Tourlourous three-pointer. 


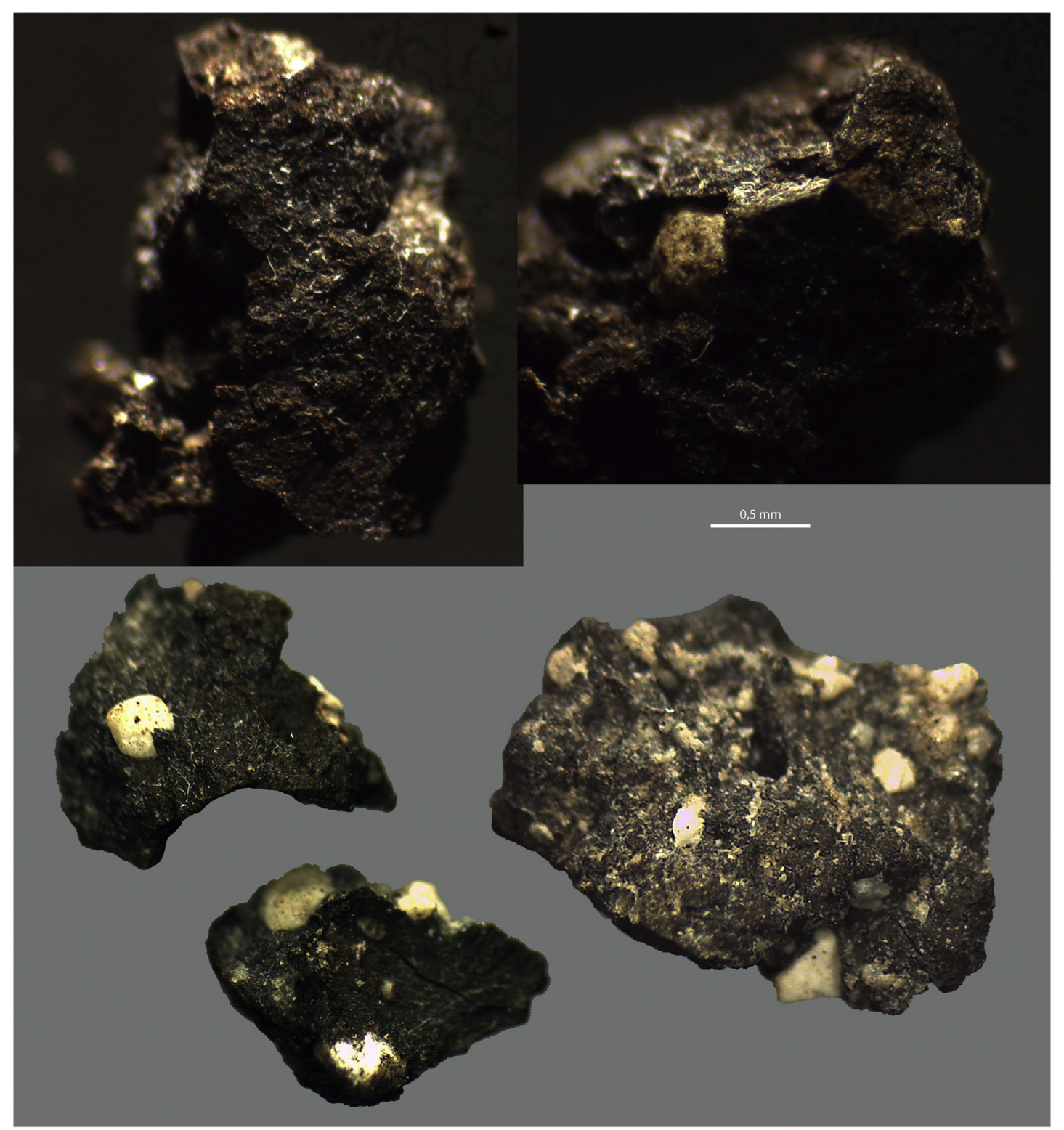

Fig. 14. Binocular photographs of the bitumen residue from three-pointer \# 385 (@ N. Serrand, Inrap). (For interpretation of the references to color, the reader is referred to the web version of this article.)

\subsection{Ligature indications}

Examination of the three-pointer has clearly shown the absence of black material on the lower face of the base: only the terminal edges of black material extending downward from the upper surface can be observed in three places at the edge of the base (Figs. 4 and 15, arrows). The black material stops at the edge of the basal worked surface, which has been abraded in order to produce a slight central groove. Thorough examination confirmed that no black material ever covered the surface of the base. This pattern suggests that, if the artefact had been tied up to a stand or a handle, direct contact would have been made between the stand/handle and the artefact's base, the latter thus not being coated with bitumen.

Moreover, the residue on both points clearly shows concentric grooves imprinted in the black material (Fig. 8). These are tentatively interpreted as imprints of cord ties, or ligature. These concentric imprints, along with the absence of black residue on the basal surface, raise a few possibilities for tying or articulating the artefact with (an) other object(s), as illustrated in Fig. 15.
Another Guadeloupean three-pointer specimen, from the site of Anse à la Gourde (AG4) and studied by Breukel (2013), shows reliable traces of cordage. It possesses shallow grooves near its ends, where microwear traces appear as striations of friction polish (Breukel, 2013: Fig. 41). Their analysis suggests the use of cords to tie down the threepointer, although they are not associated with any starch or bitumen residues.

The hypothesis that three-pointers were tied onto other objects was debated very early, for the Greater Antilles. Traces of resinous substances and worn grooves from bindings observed on the bases of Taino Chicoid three-pointers were related to some sort of attachment to other objects or supports. This suggested that such artefacts may have had multiple uses during their lives, as weapons, pestles, ensigns, enshrined idols, agricultural benefactors, community totems, etc. They thus may have been lashed to handles, bound to stone collars, or to any other support, or coated with resins or pigments (De Hostos, 1923; Fewkes, 1904, 1922, 2009 [1907]). These hypotheses were more recently debated again for the Greater Antilles (Oliver, 2007, 2009; Walker, 1993, 1997) as well as for the northern Lesser Antilles (Crock and Petersen, 

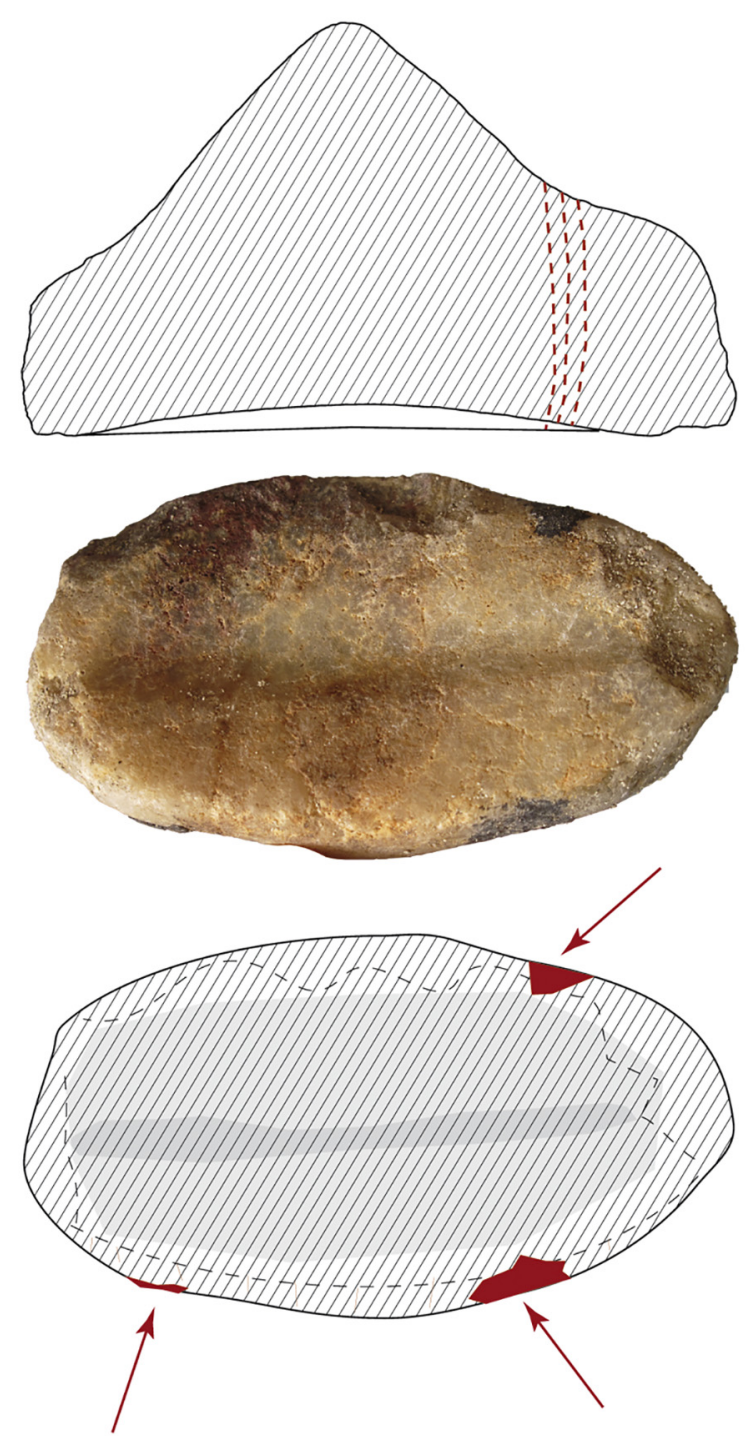

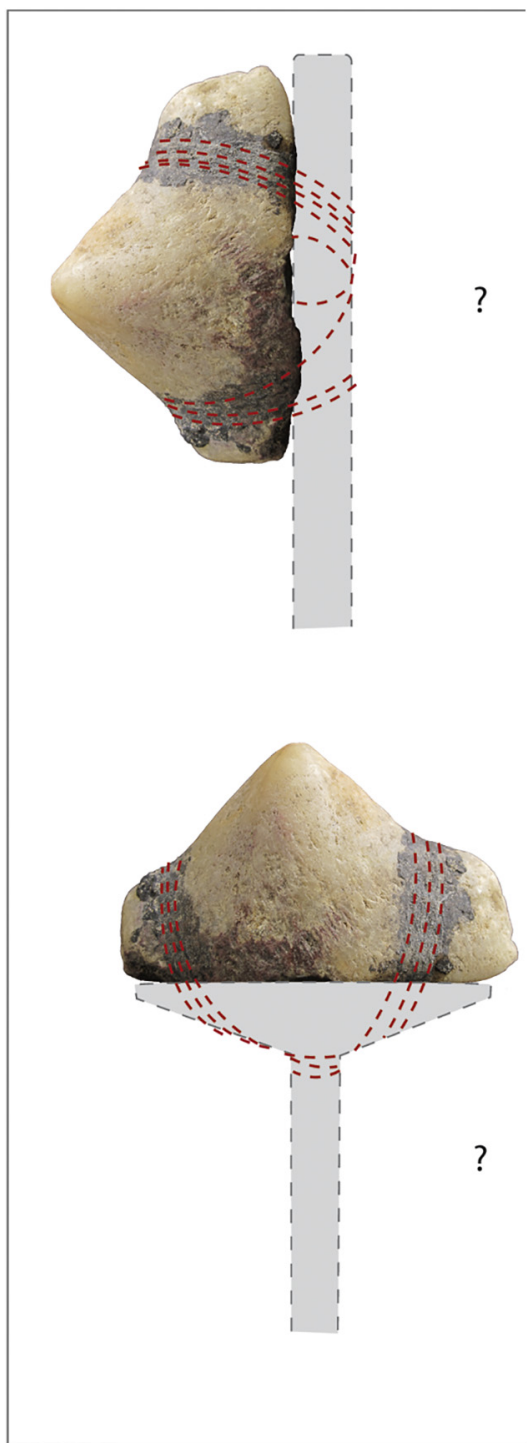

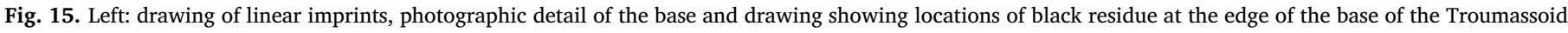

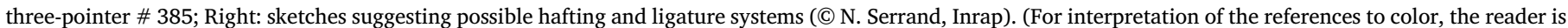
referred to the web version of this article.)

$$
\text { 2004). }
$$

In this global frame, the above described item provides clear evidence of how at least some three-pointers were incorporated into composite artefacts via their base. In contrast, the location of the black material residues on the two other specimens from Tourlourous suggests that their base was coated with resin or bitumen (no analysis has yet been carried out). It thus indicates some other mode of tying or treating these two items.

\section{Conclusion}

The iconic three-pointers left behind by the pre-Columbian Ceramic Age societies of the Lesser and Greater Antilles remain rather enigmatic. Despite much attention, many academic debates and interpretative hypotheses (Breukel, 2013: p. 18), little is still known about the significance of their shape, of their iconography and of the spiritual dimensions they once possessed and represented.

Nevertheless, beyond the fact that these objects had a spiritual dimension, they also were objects with a practical side implying ways of handling, carrying and keeping, possibly involving additional materials, the use of cords or ligatures and tarry adhesives (Ostapkowicz et al., 2017). Any clues that may indicate such treatments should not be overlooked and are important for archaeologists in the process of interpreting these objects.

The case study of the remarkably well preserved attributes of the Tourlourous/Stadium J. Bade three-pointer does more than simply add to the corpus. It offers clear indications that heretofore could only be inferred from scant evidence on similar artefacts, with no way of going further. In addition, it invites researchers to revive ways of thinking about three-pointers not only as representations embodied with "spiritthings" (zemis) but also as tools and media of the communication between human societies and other dimensions. As such, three-pointers were objects that needed to be tied, fixed on a support, joined with other materials, handled, shown, hidden, buried or otherwise manipulated in various ways.

While it may remain impossible to determine whether a specific three-pointer represented specific spirits, it may be possible to understand, for specific times and communities, how these signs may have been conventional and standardised mediators used as a kind of visual and kinetic key to convey ideas and events. This was their crucial role in maintaining relationships within the community and, possibly, between that community and transcendent, spiritual dimensions. 


\section{Acknowledgements}

This work is the result of research carried out by the National Institute of Preventive Archaeological Research (Inrap) with financial support from the city of Capesterre de Marie-Galante, Guadeloupe. We would like to thank John G. Crock for lending us a sample of bitumen from the Trinidad Pitch Lake. We also want to commend the Department of Chemistry and Industrial Chemistry of Pisa University for supporting the fine laboratory work. We would like to thank the E. Clerc Museum, Department of Guadeloupe, for the use of the SaintGermain three-pointer's photographs. The two anonymous reviewers made insightful comments on earlier versions of this paper. Finally, E. Lundberg is deeply thanked for her thorough reading and sharp-sighted contributions to this paper.

\section{References}

Alegría, R., 1981. El uso de la incrustacion en la escultura de los Indios Antillanos. Centro de Estudios Avanzados de Puerto Rico y el Caribe, and Santo Domingo: Fundación García Arévalo, San Juan, Puerto Rico.

Allaire, L., 1974. Paquemar revisited. In: Proceedings of the 5th International Congress for the Study of Pre-Columbian Cultures of the Lesser Antilles, Antigua, 1973. The Antigua National Trust \& the Antigua Archaeological Society, Antigua, pp. 117-126.

Barbotin, M., 1970. Les sites archéologiques de Marie-Galante, Guadeloupe. In: Proceedings of the 3rd International Congress for the Study of Pre-Columbian Cultures of the Lesser Antilles. National Museum, Saint-Georges, Grenada, pp. 27-44.

Barbotin, M., 1987. Archéologie antillaise, Arawaks et Caraïbes. Parc naturel de Guadeloupe, Basse-Terre (119 p.).

Bodu, P., 1985. Fouilles dans la grotte du Morne Rita (Capesterre, Marie-Galante). Notes manuscrites, SRA Guadeloupe, Basse-Terre (10 p.).

Bonnissent, D., 2010. Archéologie précolombienne de l'île de Saint-Martin, Petites Antilles. Des campements des nomades des mers aux villages des agriculteurs-potiers (3300 BC-1600 AD). Editions Universitaires Européennes, Riga, Lettonia (627 p.).

Bonnissent, D., 2011. Des microsites satellites spécialisés au Néoindien ancien à la Pointe de Folle Anse. Guadeloupe, Grand Bourg de l'île de Marie-Galante. In: Rapport Final d'Opération de Fouille, Service de l'Archéologie de Guadeloupe. DRAC Guadeloupe (88 p).

Boomert, A., 2000. Trinidad, Tobago and the Lower Orinoco Interaction Sphere: An Archaeological/Ethnohistorical Study. Cairi Publications, Alkmaar, The Netherlands (578 p.).

Boomert, A., 2001. Saladoid sociopolitical organization. In: Proceedings of the 18th International Congress for Caribbean Archaeology, Grenada, July 11-17, 1999. Association Internationale d'Archéologie de la Caraïbe, Guadeloupe, pp. 55-77.

Boomert, A., 2013. Gateway to the mainland: Trinidad and Tobago. In: Keegan, W.F., Hofman, C.L., Rodríguez Ramos, R. (Eds.), The Oxford Handbook of Caribbean Archaeology. Oxford University Press (Oxford Handbooks in Archaeology), New York, pp. 141-154.

Boomsma, E., Isendoorn, D., 2001. Caribbean explorations. In: Prospections of two Archaeological Sites in the Guadeloupean Archipelago: Cocoyer St. Charles and Anse à l'eau. MA Thesis. Faculty of Archaeology Leiden University (250 p.).

Breukel, T., 2013. Three-pointers on trial. A biographical study of Amerindian ritual artefacts from the pre-Columbian Caribbean. In: Research Master Thesis. Faculty of Archaeology, Leiden University.

Casagrande, F., 2013. Petite-Anse, Guadeloupe, Capesterre-de-Marie-Galante. In: Rapport Final d'Opération de Diagnostic, Service de l'Archéologie de Guadeloupe. Guadeloupe, DRAC (56 p.).

Chenorkian, R., 1998. Grand-Bourg de Marie-Galante. Folle Anse. In: Bilan scientifique Région Guadeloupe 1998, Service de l'Archéologie de Guadeloupe. Basse-Terre, Direction Régionale des Affaires Culturelles de Guadeloupe, pp. 19-21.

Clerc, E., 1973. Les trois-pointes des sites précolombiens de la côte nord-est de la GrandeTerre de la Guadeloupe. In: Proceedings of the 4th International Congress for the Study of Pre-columbian Cultures of the Lesser Antilles, St. Lucia 1971. Saint Lucia Archaeological and Historical Society, Castries, Saint Lucia, pp. 73-81.

Clerc, E., 1974. Le travail du coquillage dans les sites précolombiens de la Grande-Terre de Guadeloupe. In: Proceedings of the 5th International Congress for the Study of the Precolumbian Cultures of the Lesser Antilles. The Antigua Archaeological Society, Association Internationale d'Archéologie de la Caraỉbe, Antigua, pp. 127-131.

Clerc, E., 1976. Remarques sur quelques pierres à trois-pointes provenant des gisements de Grande-Terre, Guadeloupe. In: Actes du VIe Congrès International d'Etude des Civilisations des Petites Antilles, Pointe-à-Pitre, Guadeloupe 1975. Association Internationale d'Archéologie de la Caraïbe, pp. 42-43.

Colas, C., 2003. Marie-Galante «Le Tourlourous»: Fouilles de sauvetage dans un dépotoir amérindien. In: Tavárez María, C., García Arévalo, M.A. (Eds.), Actes du XXè Colloque de l'Association Internationale d'Archéologie de la Caraïbe, Saint-Domingue 2003. vol. 2. Museo del Hombre Dominicano y Fundación García Arévalo, pp. 779-788

Colas, C., Bertran, P., Chancerel, G., Chancerel, A., Richard, J.-M., 2002. Marie-Galante Le Tourlourous (97108005AH). In: Document Final de Synthèse de sauvetages urgents. Service de l'Archéologie de Guadeloupe, DRAC Guadeloupe (154p.).

Connan, J., 1988. Quelques secrets des bitumens archéologiques de Mésopotamie révélés par les analyses de géochimie organique pétrolière. Bulletin des Centres de Recherche Exploration-Production Elf-Aquitaine 12, 759-787.

Connan, J., 1999. Use and trade of bitumen in antiquity and prehistory: molecular archaeology reveals secrets of past civilizations. Philos. Trans. R. Soc. B 354, 33-50.

Connan, J., Deschesne, O., Dessort, D., 1990. L'origine des bitumes archéologiques de Ras Shamra. Bulletin des Centres de Recherche Exploration-Production Elf-Aquitaine 14 (2), 521-539.

Courtaud, P., Stouvenot, C., Gambier, D., Hérouin, S., Richard, G., Romon, T., 2005 Grottes Cadet 2 et 3. Commune de Capesterre de Marie-Galante. In: 2004. Rapport de fouille programmée. Rapport d'Opération de Fouille. Service de l'Archéologie de Guadeloupe, DRAC Guadeloupe.

Courtaud, P., Dumontier, P., Lenoble, A., Prestes Carneiro, G., Detienne, P., Fouéré, P., Grouard, S., Serrand, N., 2014. La grotte Blanchard (Commune de Capesterre de Marie-Galante, Guadeloupe). In: Opération archéologique novembre 2012. Basse Terre, SRA Guadeloupe.

Crock, J., Petersen, J., 2004. Inter-island Exchange, SHierarchy, and a Taino-related Chiefdom on the Anguilla Bank, Northern Lesser Antilles. In: Delpuech, A., Hofman, C.L. (Eds.), Late Ceramic Age Societies in the Eastern Caribbean. Oxford: Archaeopress BAR International Series, 1273; Paris Monographs in American Archaeology. vol. 14. pp. 139-156.

De Hostos, A., 1923. Three pointed stone zemi or idols from the West Indies: an interpretation. Am. Anthropol. 25, 56-71.

Durand, J.-F., Petitjean Roget, H., 1991. A propos d'un collier funéraire à Morel, Guadeloupe: les Huécoïdes sont-ils un mythe? In: Robinson, L.S. (Ed.), Proceedings of the 12th International Congress for Caribbean Archaeology, Cayenne, Guyane, 1987. Martinique: International Association for Caribbean Archaeology, pp. 51-72.

Emond, D., 1980. Contribution à la préhistoire de Marie-Galante: le site de Taliseronde. In: Mém. de Maîtrise. Université de Montréal, dépt d'Anthropologie, Faculté des Arts et Sciences (176 p).

Etrich, C., 2001. Capesterre de Marie-Galante «Tourlourous» (97108005AH): Rapport d'évaluation archéologique. In: Rapport d'Opération Inrap. Service de l'Archéologie de Guadeloupe, DRAC Guadeloupe (19 p.).

Fewkes, J.W., 1904. Porto Rican Stone Collars and Tripointed Idols. Reprinted from Smithsonian Miscellaneous Collections (Quarterly Issue). vol. 47 Smithsonian Institute, Washington (1904).

Fewkes, J.W., 1922. A prehistoric island culture area of America. In: 34th Annual Report of the Bureau of American Ethnology, 1912-1913, pp. 35-281 (Washington, D.C.).

Fewkes, J.W., 2009 [1907]. In: Curet, L.A. (Ed.), The Aborigines of Puerto Rico and Neighbouring Islands. University of Alabama Press (Caribbean Archaeology and Ethnohistory), Tuscaloosa.

Fouéré, P., Bailon, S., Bonnissent, D., Chancerel, A., Lenoble, A., Grouard, S., Mora, P., Pinçon, K., Queffelec, A., 2014. Grotte du Morne Rita, Capesterre de Marie-Galante, Guadeloupe. Notice scientifique, Bilan scientifique Région Guadeloupe 2011-2013. In: Service de l'Archéologie de Guadeloupe. Direction Régionale des Affaires Culturelles de Guadeloupe, Basse-Terre, pp. 34-37.

Fourteau, A.-M., 2009. Capesterre de Marie-Galante, stade José Bade, suivi archéologique des sondages géotechniques. In: Rapport d'Opération. Service de l'Archéologie de Guadeloupe, DRAC Guadeloupe (13 p.).

Gassies, E., 1995. Prospection - Inventaire au lieu-dit "Les Galets" sur la commune de Capesterre-de-Marie-Galante. In: Rapport d'Opération. Service de l'Archéologie de Guadeloupe, DRAC Guadeloupe.

Grouard, S., Bonnissent, D., Courtaud, P., Fouéré, P., Lenoble, A., Richard, G., Romon, T., Serrand, N., Stouvenot, C., 2014. Fréquentation amérindienne des cavités des Petites Antilles. In: Bérard, B., Losier, C. (Eds.), Archéologie Caraïbe, Taboui. vol. 2. Sidestone Press, Leiden, pp. 245-278.

Honoré, S., 2013. Évaluation archéologique du site de l'Anse du Coq, Marie-Galante, Guadeloupe, Avril 2010. In: Rapport d'Opération. Service de l'Archéologie de Guadeloupe, DRAC Guadeloupe (144 p.).

Hoogland, M., 1996. In search of the native population of Pre-Columbian Saba (400-1450 A.D.). In: Part Two. Settlements in Their Natural and Social Environment. Unpublished Ph. D. Dissertation. Rijksunversiteit, Leiden.

Hostettler, F.D., Rosenbauer, R.J., Kvenvolden, K.A., 2000. Response to comment by Bence et al. Org. Geochem. 31, 939-943.

Jacquot, F., Doumenq, P., Guiliano, M., Munoz, D., Guichard, J.R., Mille, G., 1996. Biodegradation of the (aliphatic + aromatic) fraction of Oural crude oil. Biomarker identification using GC/MS SIM and GC/MS/MS. Talanta 43, 319-330.

Keegan, W.F., 1994. West Indian archaeology. 1. Overview and foragers. J. Archaeol. Res. 2 (3), 255-289.

Keegan, W.F., 2000. West Indian Archaeology. 3. Ceramic Age. J. Archaeol. Res. 8 (2), $135-167$.

Las Casas, Fray Bartolomé de, 1957 [1560]. Historia de las Indias. In: Biblioteca de autores españoles. vol. 3 Ediciones Atlas, Madrid.

Lenoble, A., Grouard, S., Casagrande, F., Huchet, J.-B., Mallye, J.-B., Mollaret, N., Paquette-Lefebvre, J., Romon, T., Scalliet, M., Serrand, N., 2008. Histoire des peuplements animaux de la Guadeloupe au Pléistocène et à l'Holocène (15000 BC-1500 AD). In: Evaluation du potentiel des sites naturels et archéologiques de contexte karstique pour la caractérisation des étapes du peuplement animal de l'archipel guadeloupéen. Rapport étude, Diren-CNRS-MNHN (80 p., 32 fig.).

Lenoble, A., Boudadi-Maligne, M., Grouard, S., Mallye, J.-B., Queffelec, A., Stouvenot, C., 2012. Nettoyage du fossé de bord de route de Petite Anse (Capesterre-de-MarieGalante, Guadeloupe). In: Rapport de sondage archéologique. vol. 12 Service Régional de l'Archéologie, Région Guadeloupe.

Lluveras, A., Bonaduce, I., Andreotti, A., Colombini, M.P., 2010. GC/MS analytical procedure for the characterization of glycerolipids, natural waxes, terpenoid resins, proteinaceous and polysaccharide materials in the same paint microsample avoiding interferences from inorganic media. Anal. Chem. 82, 376-386. 
Lucejko, J., Connan, J., Orsini, S., Ribechini, E., Modugno, F., 2017. Chemical analyses of Egyptian mummification balms and organic residues from storage jars dated from the Old Kingdom to the Copto-Byzantine period. J. Archaeol. Sci. 85, 1-12.

Oliver, J., 1999. The 'La Hueca' problem in Puerto Rico and the Caribbean: old problems, new perspectives, possible solutions. In: Hofman, C.L., Hoogland, M.L.P. (Eds.), Archaeological Investigations on St. Martin (Lesser Antilles): The Sites of Norman Estate, Anse des Pères and Hope Estate with a Contribution to the 'La Hueca' Problem. Archaeological Studies Leiden University. vol. 4. Faculty of Archaeology, Leiden University, Leiden, pp. 253-298.

Oliver, J., 2007. Estudio acerca del significado y funciones de los aros líticos, piedras en codo y trigonolítos de Puerto Rico y La Española. El Caribe Arqueológico 10, 43-86.

Oliver, J., 2009. Caciques and Cemí Idols: The Web Spun by Taíno Rulers between Hispaniola and Puerto Rico. University of Alabama Press (Caribbean Archaeology and Ethnohistory), Tuscaloosa.

Ostapkowicz, J., Wiedenhoeft, A., Bronk Ramsey, C., Ribechini, E., Wilson, S., Brock, F., Higham, T., 2011. 'Treasures... of black wood, brilliantly polished': five examples of Taíno Sculpture from the Tenth-Sixteenth Century Caribbean. Antiquity 85 (329), 942-959.

Ostapkowicz, J., Bronk Ramsey, C., Brock, F., Higham, T., Wiedenhoeft, A., Ribechini, E., Lucejko, J., Wilson, S., 2012. Chronologies in wood and resin: AMS 14C dating of PreHispanic Caribbean wood sculpture. J. Archaeol. Sci. 39, 2238-2251.

Ostapkowicz, J., Bronk Ramsey, C., Brock, F., Cartwright, C., Stacey, R., Richards, M., 2013. Birdmen, Cemís and Duhos: material studies and AMS 14C dating of PreHispanic Caribbean wood sculptures in the British Museum. J. Archaeol. Sci. 40, $4675-4680$

Ostapkowicz, J., Brock, F., Wiedenhoeft, A., Schulting, R., 2017. Integrating the old world into the new: an 'Idol from the West Indies'. Antiquity 91 (359), 1314-1329.

Oviédo y Valdes, G.F. de, 1959. Historia general y natural de las Indias. In: Biblioteca de autores españoles. vol. 5 Ediciones Atlas, Madrid.

Pané, R., 1974 [1571]. In: Arrom, J.J. (Ed.), Relacion acerca de las antiguedades de los indios. Ediciones Siglo Veintiuno, Mexico.

Petersen, J., 1997. Taino, Island Carib, and Prehistoric Amerindian Economics in the West Indies: tropical forest adaptations to island environments. In: Wilson, S.M. (Ed.), The Indigenous People of the Caribbean. University Press of Florida (The Ripley P. Bullen series), Gainesville, pp. 118-130.

Petitjean Roget, H., 1983. De l'origine de la famille humaine ou l'étude des pierres à troispointes des Antilles. In: Proceedings of the Ninth International Congress for the Study of the Pre-Columbian Cultures of the Lesser Antilles, Santo Domingo, August 2-8, 1981. Centre des Recherches Caraïbes, Montréal, pp. 511-530.

Petitjean Roget, H., 1997. Notes on ancient Caribbean art and mythology. In: Wilson, S.M. (Ed.), The Indigenous People of the Caribbean. University Press of Florida (The Ripley P. Bullen series), Gainesville, pp. 100-108.

Petit-Jean-Roget, H., 1993. Les pierres à trois-pointes des Antilles: essai d'interprétation. Espace Caraïbe 1 (7) (24).

Raleigh, W., 1887 [1595]. The Discovery of Guiana, and the Journal of the Second Voyage Thereto by Sir Walter Raleigh. Cassell \& Company, Limited, London, Paris, New York and Melbourne.

Richardson, C., 1917. Trinidad and Bermudez Lake Asphalts and Their Use in Highway Construction. The Barber Asphalt Paving Company (October 16, 1917, p. 6).

Rodríguez Ramos, R., Pagán Jiménez, J., Hofman, C., 2013. The humanization of the insular Caribbean. In: Keegan, W.F., Hofman, C.L., Rodríguez Ramos, R. (Eds.), The Oxford Handbook of Caribbean Archaeology. Oxford University Press (Oxford Handbooks in Archaeology), New York, pp. 126-140.

Roe, P., 1982. The Cosmic Zygote: Cosmology in the Amazon Basin. Rutgers University Press, New Brunswick.

Roe, P., 1997. Just wasting away: Taíno shamanism and concepts of fertility. In: Bercht, F., Brodsky, E., Farmer, J.A., Taylor, D. (Eds.), Taíno: Pre-Columbian Art and Culture from the Caribbean. Monacelli Press, New York, pp. 124-157.

Roehl, P.O., 1993. Comparative sedimentology: bitumen pellets and lumps in modern and ancient shallow water carbonate deposits. In: Proceedings of the 6th Symposium on the Geology of the Bahamas, 1993. Bahamas and New Mexico, pp. 131-148.

Rouse, I., 1986. Migrations in Prehistory: Inferring Population Movement from Cultural
Remains. Yale University Press, New Haven.

Rouse, I., 1992. The Tainos: Rise and Decline of the People who Greeted Columbus. Yale University Press, New Haven (211 p).

Rouse, I., Alegría, R., 1990. Excavations at Maria de la Cruz Cave and Hacienda Grande Village Site, Loiza, Puerto Rico. In: Yale University Publications in Anthropology, 80 Yale University Press, New Haven.

Rouse, I., Cruxent, J., 1963. Venezuelan Archaeology. Caribbean Series 6. Yale University Press, New Haven.

Serrand, N., 2010. Stade José Bade, Guadeloupe, Marie-Galante, Capesterre. Rapport final d'opération. In: Rapport d'Opération de diagnostic. Service de l'Archéologie de Guadeloupe, DRAC Guadeloupe (60 p).

Serrand, N., Cummings, K.S., 2014. Occurences of exogenous freshwater mussel shells (Bivalvia:Unionoida) during the precolumbian Ceramic Age of the Lesser Antilles. In: Szabó, K., Dupont, C., Dimitrijević, V., Gómez, Gastélum L., Serrand, N., 2014 (Eds.), Archaeomalacology: Shells in the Archaeological Record. BAR Series 2666, pp. 65-75.

Serrand, N., Bonnissent, D., Bertran, P., Casagrande, F., Dietrich, A., Grouard, S., Orsini, S., Ribechini, E., Romon, T., Sellier-Segard, N., 2016a. Guadeloupe, Capesterre-deMarie-Galante. Les occupations cedrosan-saladoïde et troumassan-troumassoïde de Tourlourous. In: Rapport final d'opération de fouille archéologique. vol. 2 Direction des Affaires Culturelles Guadeloupe, Service Régional de l'Archéologie (404 p).

Serrand, N., Bonnissent, D., Bertran, P., Casagrande, F., Grouard, S., Romon, T., SellierSegard, N., 2016b. Preventive excavation of a portion of the Tourlourous Site, Capesterre de Marie-Galante, Guadeloupe, F.W.I. preliminary results. In: Haviser, J.B., Velasquez, C. (Eds.), Proceedings of the 26th International Congress for Caribbean Archaeology, Saint-Martin 2015. CD format, SIMARC Heritage Series No. 10.

Siegel, P., 1992. Ideology, power, and social complexity in Prehistoric Puerto Rico. In: Unpublished Ph.D. Thesis. State University of New York, Binghamton.

Siegel, P., 2010. Continuity and change in the evolution of religion and political organization on Pre-Columbian Puerto Rico. J. Anthropol. Archaeol. 29, 302-326.

Stouvenot, C., 2004. Le site de Bas-de-la-Source rive droite, commune de Saint-Louis de Marie Galante, Guadeloupe. In: Bilan scientifique Région Guadeloupe 2004, Service de l'Archéologie de Guadeloupe. Direction Régionale des Affaires Culturelles de Guadeloupe, Basse-Terre, pp. 38-39.

Stouvenot, C., 2005. Capesterre de Marie-Galante. Grotte Blanchard. Notice scientifique. Bilan scientifique Région Guadeloupe 2005. In: Service de l'Archéologie de Guadeloupe. Direction Régionale des Affaires Culturelles de Guadeloupe, BasseTerre (26).

Stouvenot, C., Grouard, S., Bailon, S., Bonnissent, D., Lenoble, A., Serrand, N., Sierpe, V., 2014. L'abri sous roche Cadet 3 (Marie-Galante): un gisement à thanatocénoses et vestiges archéologiques précolombiens. In: Bérard, B., Losier, C. (Eds.), Archéologie Caraïbe, Taboui 2. Sidestone Press, Leiden, pp. 77-102.

Testart, A., 2006. Interprétation symbolique et interprétation religieuse en archéologie. L'exemple du taureau à Çatal Höyük. Paléorient 32 (2), 23-57.

Veloz Maggiolo, M., 1970. Los trigonolitos Antillanos: Aportes para un intento de reclasificacion e interpretacion (1). Revista Española de Antropologia Americana 5, $317-340$.

Veloz Maggiolo, M., 1991. Panorama histórico del Caribe precolombino. Banco Central de la República Dominicana, Quinto Centenario del descubrimiento de America, Santo Domingo (262 p.).

Walker, J., 1993. Stone collars, elbow stones and three-pointers and the nature of Taíno ritual and myths. In: Unpublished Ph.D. Thesis. Washington State University, Pullman.

Walker, J., 1997. Taíno stone collars, elbow stones, and three-pointers. In: Bercht, F., Brodsky, E., Farmer, J.A., Taylor, D. (Eds.), Taíno: Pre-Columbian Art and Culture from the Caribbean. Monacelli Press, New York, pp. 80-91.

Wang, Z., Stout, S.A., Fingas, M., 2006. Forensic fingerprinting of biomarkers for oil spill characterization and source identification. Environ. Forensic 7, 105-146.

Wing, E., Wing, S.R., 1995. Prehistoric ceramic age adaptation to varying diversity of animal resources along the West Indian Archipelago. J. Ethnobiol. 15 (1), 119-148. 